\title{
ŠIBENICE JAKO SOUČÁST KULTURNÍ KRAJINY RANÉHO NOVOVĚKU
}

\section{PETR SOKOL}

\begin{abstract}
Abstrakt: Popraviště, zejména pak šibenice, patřila k běžným prvkům raně novověké kulturní krajiny. Zjejí role symbolu fungováni spravedlnosti a výsady města a z povahy prováděných trestů vyplývaly zásady pro jeji umistění. Šibenice představovaly dominantní prvek zázemí města. Jako jejich standardní součást se objevuji na řadě vyobrazeni měst i na mapách a plánech. Právě z ikonografických a kartografických pramenů lze studovat nejen vlastni typ popraviště a jeho topografickou charakteristiku (umistění popraviště vỉči městu a cestám, morfologie místa s popravištěm, pomístní názvy), ale i vzhled okolni přměstské krajiny, jejiž součástí se popraviště stávala a již spoluvytvářela.
\end{abstract}

Klíčová slova: šibenice - popraviště - město - raný novověk - kulturní krajina - veduty - historické mapy.

\section{Gallows as Part of the Cultural Landscape in the Early Modern Age}

Abstract: Sites of execution and especially those where gallows stood were among the elements typical of the cultural landscape in the early modern age. The principles behind their location were dictated by the role of the gallows as a symbol of justice and town privileges, and by the nature of punishment. Gallows were dominant features of the urban hinterland, and appear in a number of pictures of towns, on maps and on plans as standard items. Iconographic and cartographic sources enable the study of not only the types of gallows and their topographic characteristics (location of the gallows in relation to a town and routes to and by it, morphology of the site, local names), but also of the form of the surrounding landscape of which the gallows formed a part, and to which they lent shape.

Key words: gallows - site of execution - town - early modern age - cultural landscape - vedutas - historical maps.

Existence šibenic u královských a řady poddanských měst disponujících hrdelním právem byla v období 16.-18. století běžnou záležitostí. Objekty sloužící k vykonání běžného hrdelního trestu, jakým bylo oběšení, i dalších forem tělesných a hrdelních trestů se stávaly důležitou městskou stavbou symbolizující výsady města a fungování spravedlnosti. Současně šlo o místo, kde byli pohřbíváni odsouzenci i sebevrazi, a šibenice se tak stávala místem na jedné straně značně potřebným, na druhé straně o to více odpuzujícím a tajemným zároveň. Raný novověk je také dobou nejen rozmachu kriminality a soudnictví, ale v důsledku toho i budování šibenic. Ty mají v této době často podobu zděné či částečně zděné stavby, obvykle kruhového či pravoúhlého půdorysu, někde se však stále vyskytují jednoduché dřevěné šibenice, jejichž základní typy jsou známy ze středověkých vyobrazení. ${ }^{1}$

Pro existenci stabilních a trvanlivých zděných šibenic musely být splněny tyto základní podmínky: ustálení výkonu hrdelního práva, ustálení speciálního exekučního místa a dostatečné množství deliktů postižitelných hrdelními tresty, což souvisí s nárůstem hrdelních trestů, kriminalizace a kriminality. Všechny uvedené podmínky byly již v raném novověku splněny a ve větší míře se tak objevují pevné stavby (z některých vyobrazení známé již z pozdního středověku), dochované v některých případech ve formě ruin dodnes.

V období raného novověku bylo popraviště jednou z významných městských staveb. Představovalo symbol politické samostatnosti a autonomie (zejména v politicky rozdrobeném prostoru Svaté říše římské národa německého), městských práv a fungující spravedlnosti. Popraviště, zejména vizuálně nápadné šibenice, se stávala součástí raně novověké kulturní krajiny v zázemí sídel.

V Čechách před reformami hrdelního soudnictví v roce 1765 existovalo 384 městských hrdelních soudů, na Moravě 201 (Francek 1995, 188; Roučka 1957, 126-128, příloha 1; Štarha 1995, 25). Přibližně tolik bylo i popravišt', především šibenic jakožto typu častějšího. Některá města

1 K typologii z české literatury Sokol 2003, 751-755; Sokol-Hajšman 2010, 96-97; ze zahraniční např. Evers 2008, 447-455; Wojtucki 2009, $19-48$. 
však disponovala i více popravišti (více šibenic, nebo šibenice a stínadla), takže jejich skutečný počet byl větší než počet obcí s hrdelním právem.

Prostorový vztah město - popraviště byl určen symbolickými i praktickými důvody: Podstatný byl dostatečný odstup od obytné zóny, současně blízkost důležité komunikace a v rámci možností dominantní a exponovaná poloha. Z krajinného hlediska představovala šibenice externí součást městského organismu a jeho zázemí, zpravidla dominantní prvek v krajině, jeden z prvních objektů poutající na sebe pozornost při př́ichodu do města, doklad způsobu využití a významu některých oblastí městského extravilánu (spolu s mrchovišti, židovskými hřbitovy, leprosárii...) a indikátor odlesnění a komunikací.

Tento článek je koncipován jako zobecňující, průřezové či výchozí zpracování tématu s ilustrativními ukázkami z různých oblastí, dokládajícími předloženou charakteristiku. Záměrně nejde o podrobné analytické zpracování vymezené oblasti či konkrétní lokality nebo o analýzu pramenů na prríkladu jedné konkrétní lokality s přesahem do vývoje krajiny daného místa či o detailní topografické charakteristiky vybraných lokalit. ${ }^{2}$

\section{Prameny k studiu vzhledu raně novověké kulturní krajiny}

Studium objektů typu šibenic, případně jiných popravišt', jakožto součástí krajiny vychází především z ikonografických pramenů - vedut, knižních a letákových vyobrazení (rytin, ilustrací), z kartografických pramenů (mapy, plány měst) a menším dílem prímo z hmotných pramenů nemovité povahy (relikty popravišt'). V kombinaci alespoň prvních dvou skupin pramenů lze sledovat vzhled okolí popraviště a využití širšího prostoru v rámci sídelního celku, trasy komunikací a vazbu popraviště na ně, pomístní názvy a charakteristiku umístění šibenic (vzdálenost od města, reliéf apod.).

\section{Popraviště v ikonografických pramenech}

Veduty (pohledy na města) představují pro období raného novověku stěžejní pramen ke studiu krajiny a sídel i jednotlivých objektů. Jejich věrohodnost však bývá značně kolísavá a závislá na účelu vzniku zobrazení a tehdejších postupech, neodpovídající často dnešní dokumentaristické představě zachycení skutečnosti.

Svou četností zobrazení popravišt' představují veduty i mapy a plány, na rozdíl od lokalit dotčených archeologickými výzkumy, podklady ke kvantitativnímu zpracování jednotlivých sledovaných jevů. Popularita kartografického i pohledového zobrazování i tematiky trestů v kombinaci s knihtiskem vedla od počátku raného novověku k šíření těchto děl i vyobrazení samotných popravišt' a dějů na nich se odehrávajících (martyria světců, zobrazení v právních spisech). Detaily zobrazení byly závislé na rozvoji pozdně středověkých a raně novověkých uměleckých technik (Evers 2008, 444). U vedut, objevujících se od konce 15. století, šlo zejména o dřevořez a mědirytinu.

Při čerpání informací z vedut (analogicky i u nejstarších mapových děl) je nutné zohlednit zkreslení výsledného pohledu, dané použitím fiktivní či složené perspektivy, zdůrazněním vertikality, záměrným zvýrazněním či posunutím důležitých objektů nebo různou mírou typizace, projevující se v případě šibenic rozdílným zobrazením na různých vedutách (Evers 2008, 445-446).

Jedny z nejstarších vedut obsahuje tzv. Würzburské album zachycující řadu středoevropských měst v letech 1536-1537 (pro mnohá z nich jde o nejstarší zobrazení). Šibenice na těchto vedutách jsou často pojaty jako dominantní stavby v popředí měst či na horizontu. Obvykle je patrná vyvýšená poloha šibenic a jejich typ (obr. 1). Problematická však může být skutečná

2 Údaje o vzdálenosti popravišt’ od měst, převýšení jejich polohy apod. jsou uváděny obvykle v „materiálových“ pracích věnujících se konkrétní lokalitě či v souhrnném ,soupisovém“ zpracování, jejichž obsahem je i základní polohopisná charakteristika popravišt'. Některé z těchto prací a jejich zjištění jsou v článku uvedeny, stejně jako práce zabývající se jednou lokalitou a jejím vývojem. 


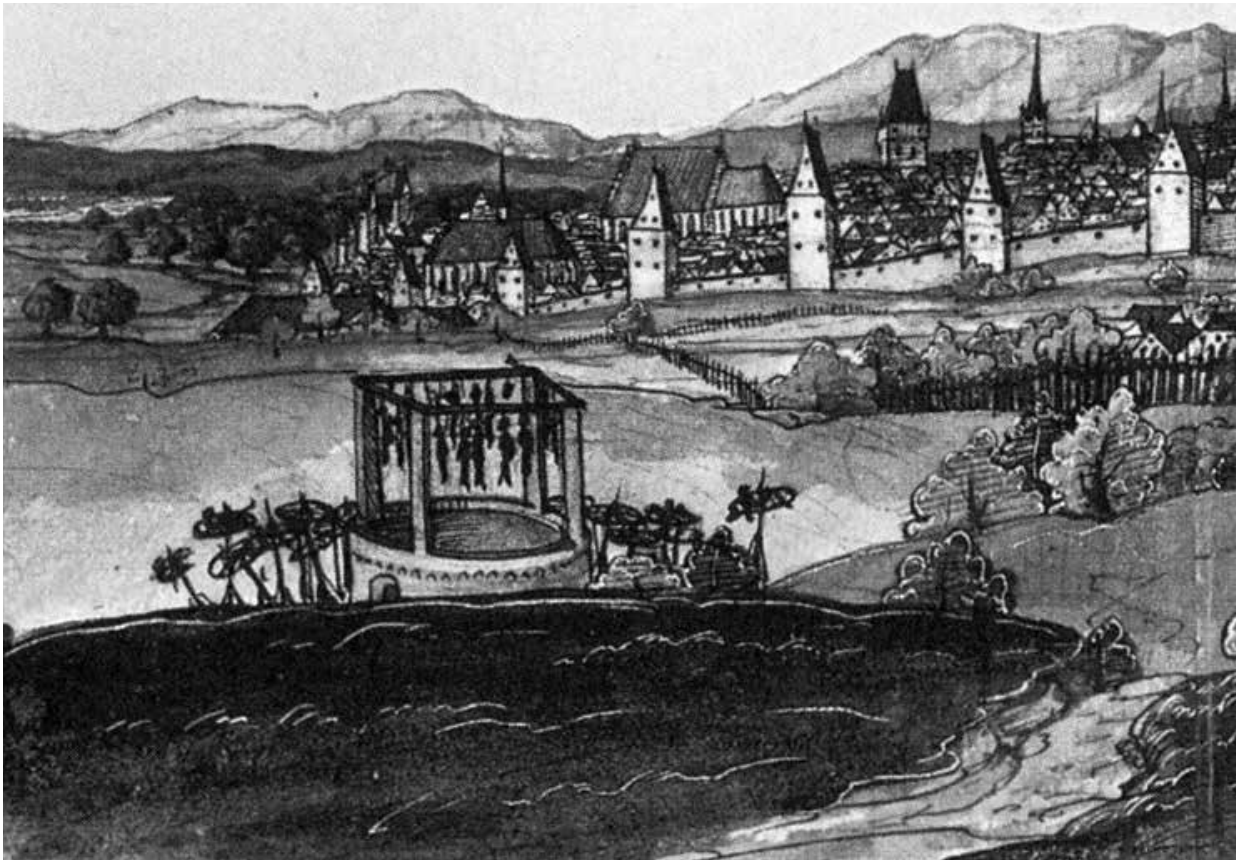

Obr. 1. Vratislav, tzv. Würzburské album, pravděpodobně Mathias Gerung 1537. Podle Marsch-Biller-Jacob 2001. Abb. 1. Breslau, sog. Würzburger Album, wahrscheinlich Mathias Gerung 1537. Nach Marsch-Biller-Jacob 2001.

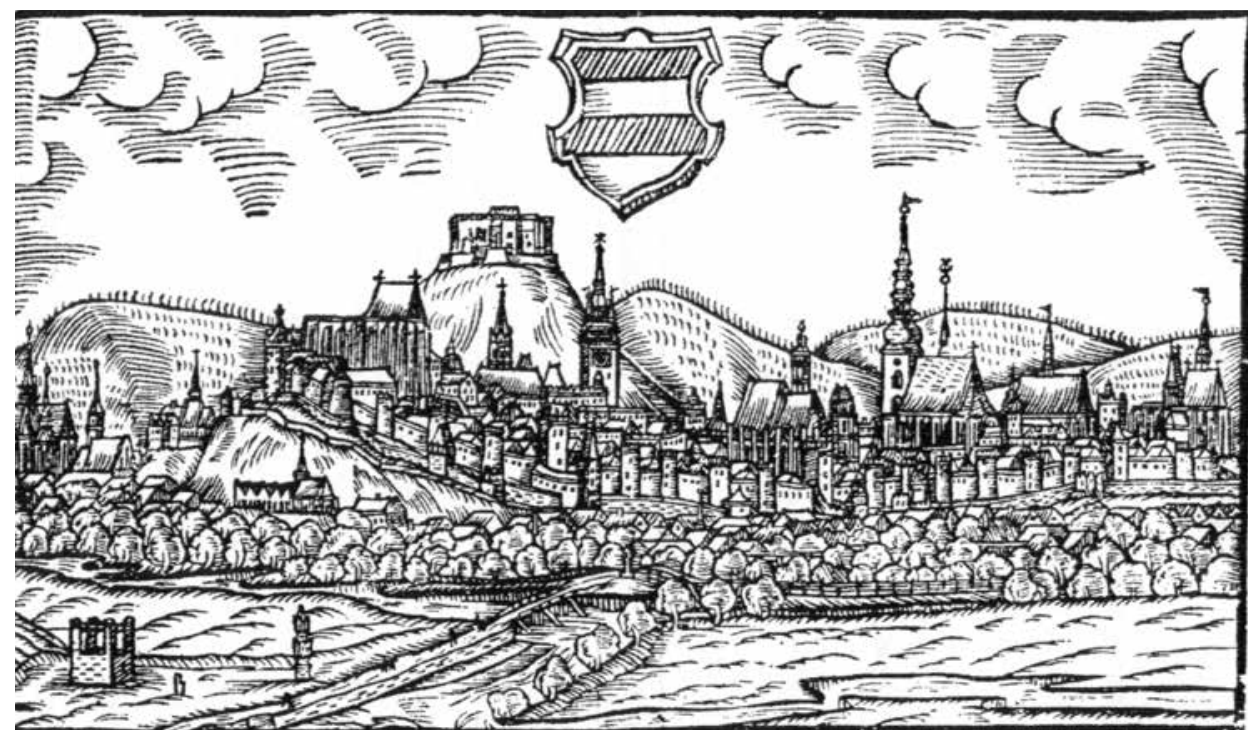

Obr. 2. Brno, J. Willenberg, kolem 1593. Zděná šibenice pravoúhlého půdorysu se čtyřmi pilíři u jedné z cest do města (vlevo dole). Zdroj https://cs.wikipedia.org.

Abb. 2. Brno, J. Willenberg, um 1593. Aufgemauerter Galgen mit rechteckigem Grundriss und vier Pfeilern an einem in die Stadt führenden Wege (links unten). Quelle https://cs.wikipedia.org. 


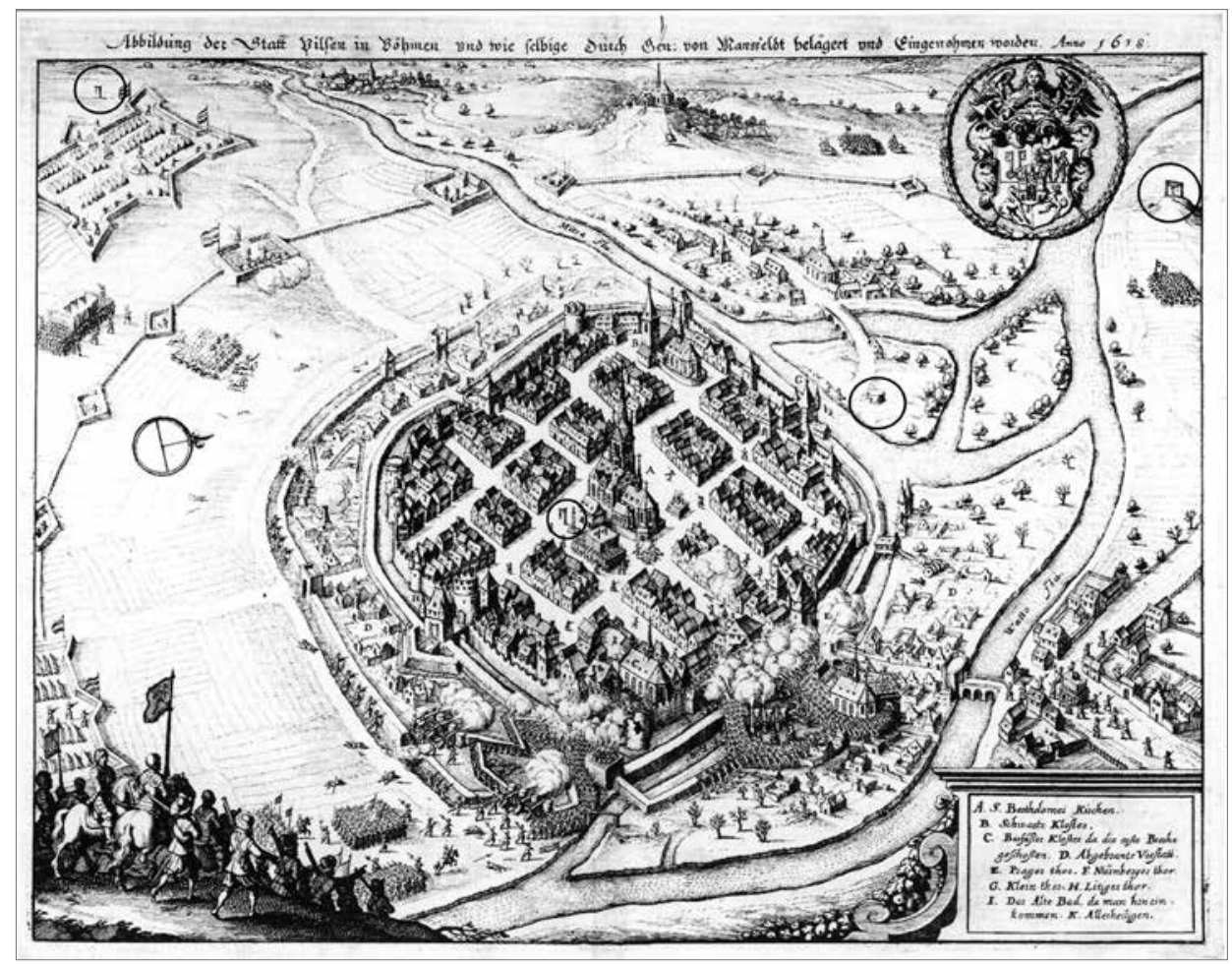

Obr. 3. Plzeň, mědirytina z dílny Meriana st., před 1635, zobrazující dobytí města vojskem Arnošta Mansfelda v roce 1618. Na jednom zobrazení města jsou zachyceny všechny obvyklé typy popravišt' v typickém prostorovém kontextu vůči městu: stabilní šibenice (vpravo nahoře) v odstupu od města, výstražná či př́ležitostná šibenice na náměstí v blízkosti pranýře, stínadla na předměstí a šibenice patř́íí $k$ táboru obléhatelů (vlevo nahoře). Předobrazem tohoto vyobrazení byla rytina Georga Kellera z roku 1619. Podle Mergl 1995.

Abb. 3. Pilsen, Kupferstich aus der Werkstatt von Merian dem Älteren, vor 1635, Darstellung der Einnahme der Stadt durch die Armee von Ernst von Mansfeld im Jahr 1618. Auf einer Darstellung der Stadt werden alle üblichen Richtstättentypen im typischen räumlichen Kontext gegenüber der Stadt festgehalten: stabiler Galgen (rechts oben) im Abstand zur Stadt, Abschreckungs- oder Gelegenheitsgalgen auf dem Marktplatz in der Nähe eines Prangers, zum Lager der Belagerer gehörender Rabenstein und Galgen in der Vorstadt (links oben). Als Vorlage für diese Darstellung diente ein Kupferstich von Georg Keller aus dem Jahr 1619. Nach Mergl 1995.

vzdálenost od města, vzhled nejbližšího prostoru a charakter krajiny, což bylo u těchto vedut pojímáno pouze ilustrativně a schematicky (Ježek 1996).

Pro česká a moravská města mají význam zejména veduty od Jana Willenberga z přelomu 16. a 17. století. Tato vyobrazení jsou zpravidla věrohodná a mají nezanedbatelnou dokumentační hodnotu (obr. 2). Šibenice jsou na těchto vedutách znázorněny jako běžná součást nejbližšího okolí města a velmi pravděpodobně $\mathrm{v}$ jejich skutečné poloze a podobě.

Významnými soubory vedut především pro říšská, ale i česká města jsou díla M. Meriana st. a následně i M. Meriana ml. Theatrum Europeaum a Topographia Germaniae, převážně z první poloviny 17. století (obr. 4, 7, 8). Šibenice jsou na těchto vedutách vzhledem k širšímu prostorovému záběru vedut a zejména $\mathrm{v}$ Theatru Europeau i vzhledem $\mathrm{k}$ pozornosti soustředěné na válečné události zobrazeny s menší detailností než např́iklad u Willenberga. Přesto však z prostorového hlediska obsahují informace o lokaci popravišt' a jejich vztahu k městu, cestám, reliéfu, méně pak již o charakteru okolní krajiny. 


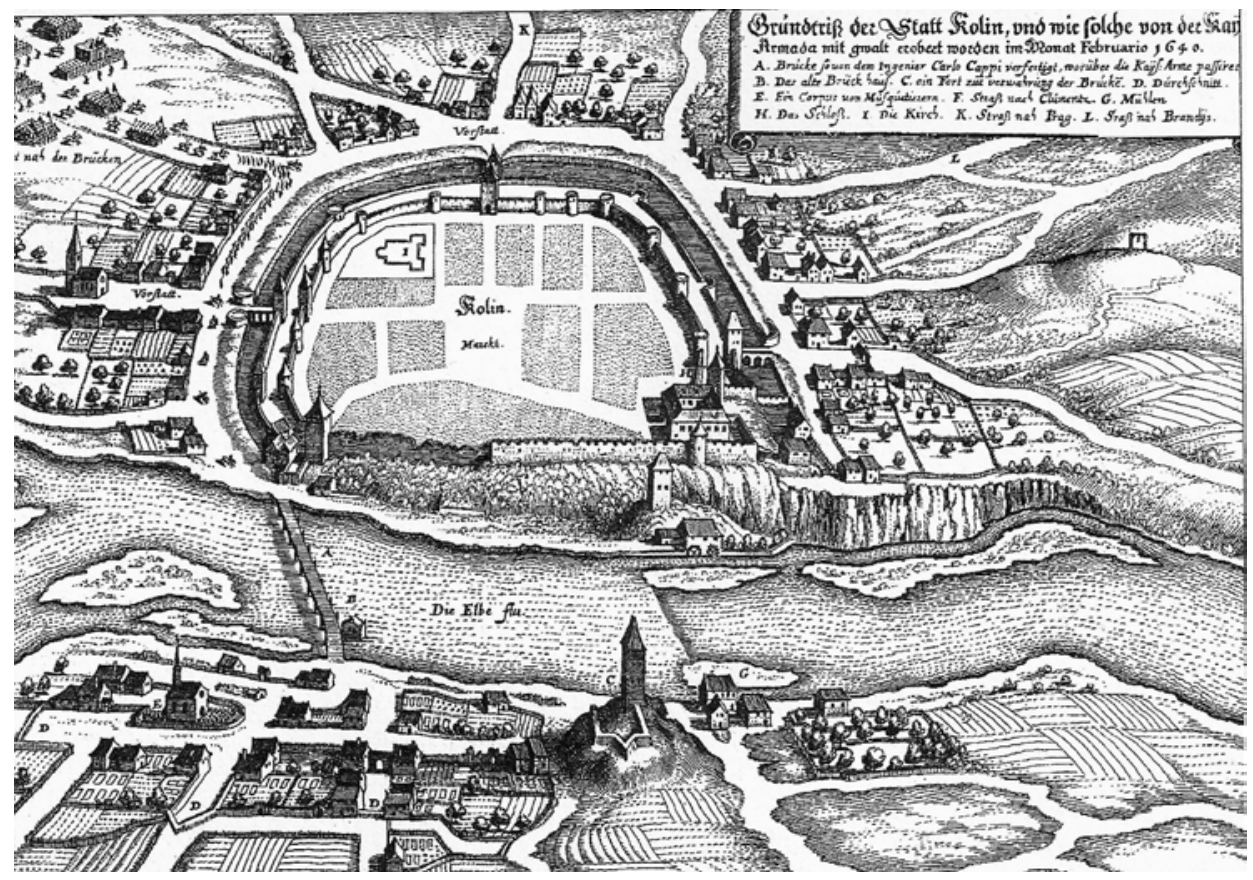

Obr. 4. Kolín, 1640. Situování šibenice v kontextu jednotlivých zón městského a příměstského prostoru. Vlastní nejužší prostor představuje jádro města s pásem opevnění, navazuje pás předměstí s usedlostmi a zahradami, vnější zónu představují polnosti a intenzivně využívaný prostor navazující na předměstí. Šibenice byla situována zpravidla do této třetí, vnější zóny, nejlépe k její vnější hranici. Podle Klučina 2000.

Abb. 4. Kolín, 1640. Lage eines Galgens im Kontext der einzelnen Zonen des Stadt- und Vorstadtraumes. Der eigentlich engste Raum war der Stadtkern mit dem Befestigungsstreifen, daran schließt der Vorstadtstreifen mit Bauernhöfen und Gärten an, die äußere Zone besteht aus an die Vorstadt anschließendem Ackerland und intensiv genutzem Raum. Der Galgen wurde in der Regel in dieser dritten, äußeren Zone aufgestellt, am besten an deren äußeren Grenze. Nach Klučina 2000.

Uvedené př́iklady sérií vedut zdaleka nepředstavují ucelený výčet zobrazení raně novověkých měst. Ikonografických pramenů tohoto typu existuje značné množství, jejich dohledávání získává na důležitosti především ve spojení se studiem konkrétního města či oblasti.

Řada měst disponuje vedutami z dílny různých autorů, podávajícími informace různé kvality. V některých případech lze najít i takové, na kterých je zobrazeno více městských popravišt', at' již díky stanovišti autora předlohy, nebo v důsledku použití kombinované perspektivy se snahou dostat do zobrazení co největší prostor a co největší počet objektů. Př́íkladem jsou veduty Plzně zobrazující dobytí města vojskem generála Arnošta Mansfelda v listopadu 1618. Řada zobrazení, zahájená roku 1619 a pokračující podle původní předlohy v průběhu 17. století (Mergl 1995; Sokol-Hajšman 2010, 94-96), zachycuje nejen stabilní šibenici na vyvýšené ŕíční terase za městem, ale i krátce existující stínadla na jednom z předměstí, provizorní či výstražnou šibenici (související zřejmě s podmínkami obleženého města) na náměstí poblíž pranýře a rovněž jednoduchou dřevěnou šibenici u polního ležení obléhatelů (obr. 3). Tato jedna veduta tak představuje zhutněnou obrazovou informaci o lokaci jednotlivých typů městských popravišt' v prostorovém kontextu města a jeho okolí.

Zatímco přechodná či výstražná popraviště bývala stavěna $v$ jádru samotného města, na nejdůležitějším veřejném prostranství - náměstí, stínadla se pak nacházela v hradebním pásu či navazujícím prostoru předměstí poblíž městských bran. Šibenice stávaly ve větším odstupu od města, na vyvýšené či jinak dominantní poloze v blízkosti jedné z hlavních cest nebo 


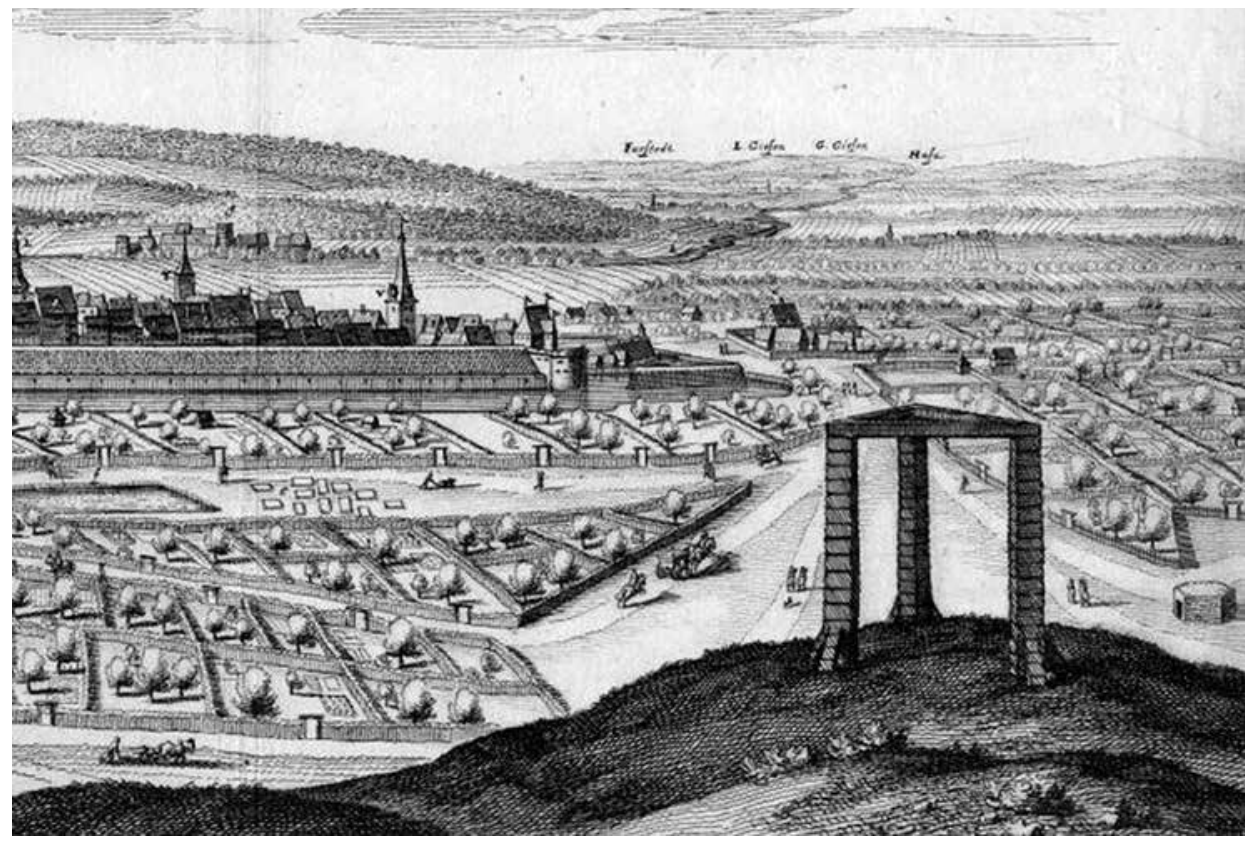

Obr. 5. Hildesheim, 1653. Umístění šibenice v kontextu př́městské krajiny, v dominantním místě na hranici intenzivně využívaného prostoru zahrad a polí. Archiv autora.

Abb. 5. Hildesheim, 1653. Lage des Galgens im Kontext der Landschaft des Stadtumlandes an einem dominanten Ort an der Grenze zum intensiv genutzten Raum von Gärten und Feldern. Archiv des Verfassers.

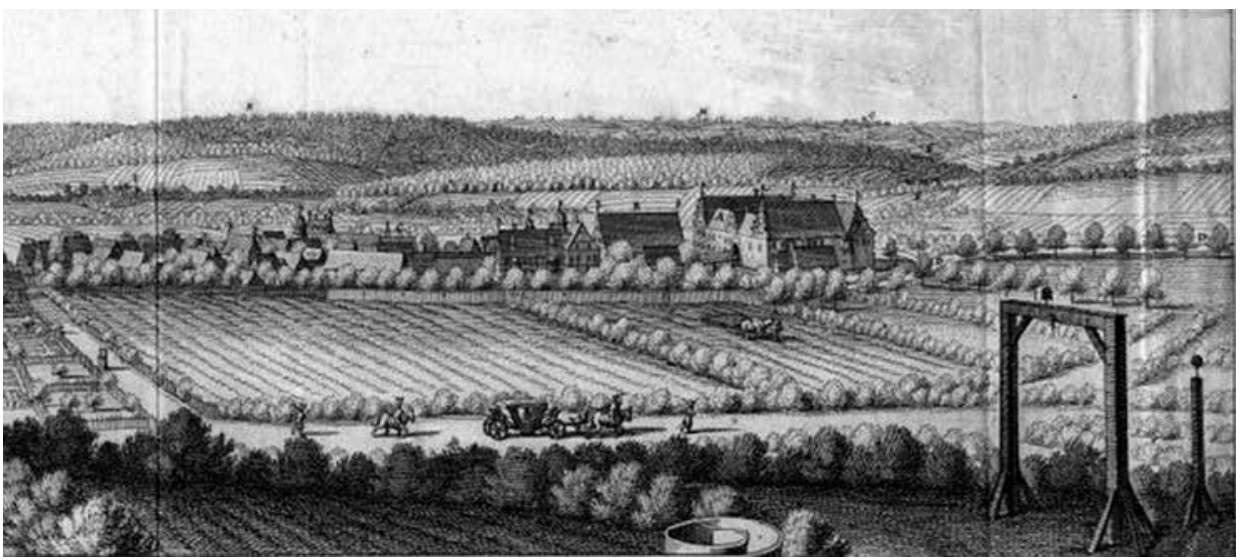

Obr. 6. Louny, 17. století. Obdobný př́íklad umístění šibenice v kontextu příměstské krajiny, v dominantním místě na hranici intenzivně využívaného prostoru zahrad a polí. Archiv autora.

Abb. 6. Louny, 17. Jahrhundert. Ähnliches Beispiel für die Lage des Galgens im Kontext der Landschaft des Stadtumlandes an einem dominanten Ort an der Grenze zum intensiv genutzten Raum von Gärten und Feldern. Archiv des Verfassers.

jejich rozcestí, pokud možno u hranic městských pozemků. Toto prostorové rozložení popravišs' úzce souviselo s rozdílnými druhy hrdelních trestů a jejich symbolickým vnímáním společností i praktickými dopady na život v okolí popravišt' (k tomu podrobněji např. Evers 2008, 457-461; Sokol 2009, 9-11; Wojtucki 2009, 49-69; Sokol-Hajšman 2010, 78-79). 
Z vedut zejména druhé poloviny 17. století a z 18. století je velmi zřetelné situování šibenic ve vztahu k uspořádání městského a příměstského prostoru a ke vzhledu okolní krajiny. Zatímco pro vlastní areál města vymezený opevněním a navazující pás předměstí s usedlostmi a zahradami můžeme předpokládat existenci pouze výše zmíněných př́íležitostných šibenic a méně častých stínadel, šibenice vyrůstaly v další prostorové zóně tvořící příměstskou krajinu - mezi polnostmi a pastvinami navazujícími na předměstské zahrady, a to při zohlednění výše uvedených kritérií (dostatečný odstup od města, dostupnost, viditelnost). Někdy šibenice zviditelňovala a symbolizovala okraj intenzivně využívaného příměstského prostoru a představovala jednu $\mathrm{z}$ jeho dominant (obr. 4).

Krajinu mezi městskými hradbami a šibenicí vyplňovaly předměstské bloky zástavby nebo jednotlivé usedlosti a zahrady, přecházející do polí a luk (obr. 5, 6). Vlastní nejbližší okolí šibenice nepředstavovalo přitom žádné odlehlé místo, v důsledku blízkosti frekventované cesty mezi městem a okolím šlo o místo vcelku exponované.

Specifický typ veduty představuje dřevořez K. Bechtelera z roku 1623 zachycující útěk Fridricha Falckého z Prahy po bitvě na Bílé hoře (obr. 9). Východně od Nového Města pražského je znázorněno návrší s polygonální zděnou šibenicí na vrcholu, s jednoduchou branou při úpatí jako vstupem do areálu popraviště a s kruhovými stínadly poblíž této brány. U brány i šibenice jsou vztyčena na kůlech kola pro vplétání těl odsouzenců. V tomto př́ípadě se zdá, že značná část návrší nedaleko městských hradeb, ne-li návrší celé, byla vymezena pouze pro areál popraviště.

Dalším typem ikonografických pramenů k šibenicím a jejich umístění v krajině jsou knižní a letákové ilustrace. Ve srovnání s vedutami je jejich přesnost, co se týče lokace šibenic i jejich typu pro danou lokalitu, méně spolehlivá a mnohdy zřejmě nebylo toto hledisko při vzniku vyobrazení ani podstatné. Zřetelné jsou však obecné rysy šibenic, jejich umístění v krajině a vůči městu a charakter areálů popravišt'. Na vyobrazení bonnské šibenice, které má z hlediska prostorových vztahů značně schematický charakter, vidíme areál popraviště tvořený dřevěnou třísloupovou šibenicí a větším počtem kol vztyčených na kůlech s těly odsouzenců. Areál se nachází ve volné nezalesněné krajině poblíž cesty na dohled od města (obr. 10). Z hlediska hodnověrnosti prostorového kontextu je spolehlivá ilustrace z kroniky města Chebu, jejímž autorem (včetně ilustrací) byl poslední chebský kat Karel Huss (obr. 11). Ve svahu blíže k městu jsou vyobrazena kruhová zděná stínadla, výše na vrcholku návrší pak zděná šibenice pravoúhlého půdorysu. Umístění obou objektů vůči hlavním cestám i charakter reliéfu odpovídá dnešní situaci, ohledně umístění šibenice pak i výše zmíněné Merianově vedutě z roku 1663. Zatímco ve svahu v okolí

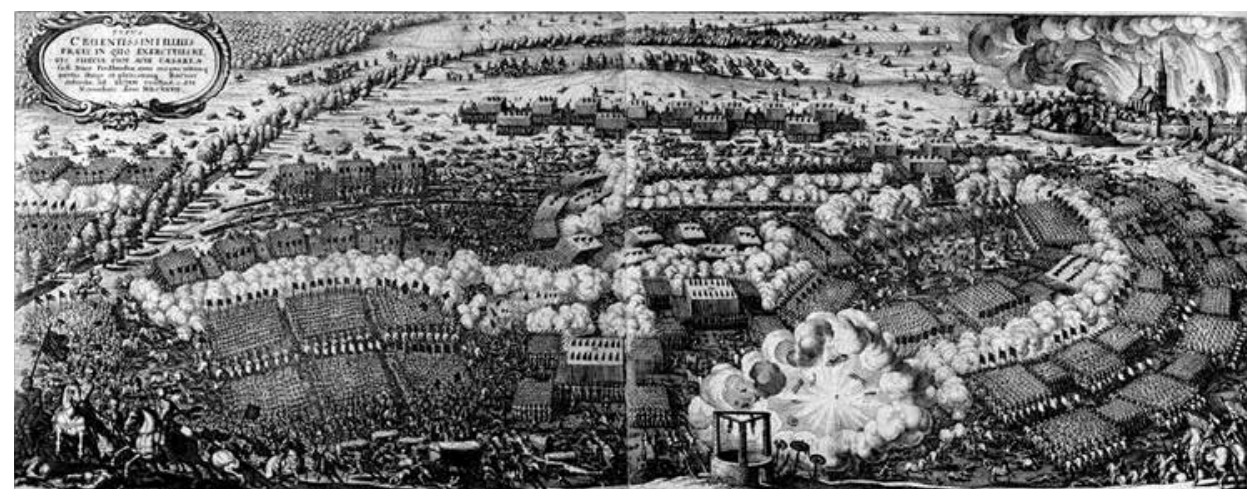

Obr. 7. Bitva u Lützenu, 16. listopadu 1632. Šibenice byla díky své dominantní poloze v zázemí města využita jako opěrný bod v týlu vojska. Rytina Matthäuse Meriana, Theatrum Europaeum, 1646. Zdroj https://en.wikipedia.org.

Abb. 7. Schlacht bei Lützen, 16. November 1632. Der Galgen wurde dank seiner dominanten Lage im Stadthinterland als Stützpunkt im Heeresrücken genutzt. Kupferstich von Matthäus Merian, Theatrum Europaeum, 1646. Quelle https://en.wikipedia.org. 


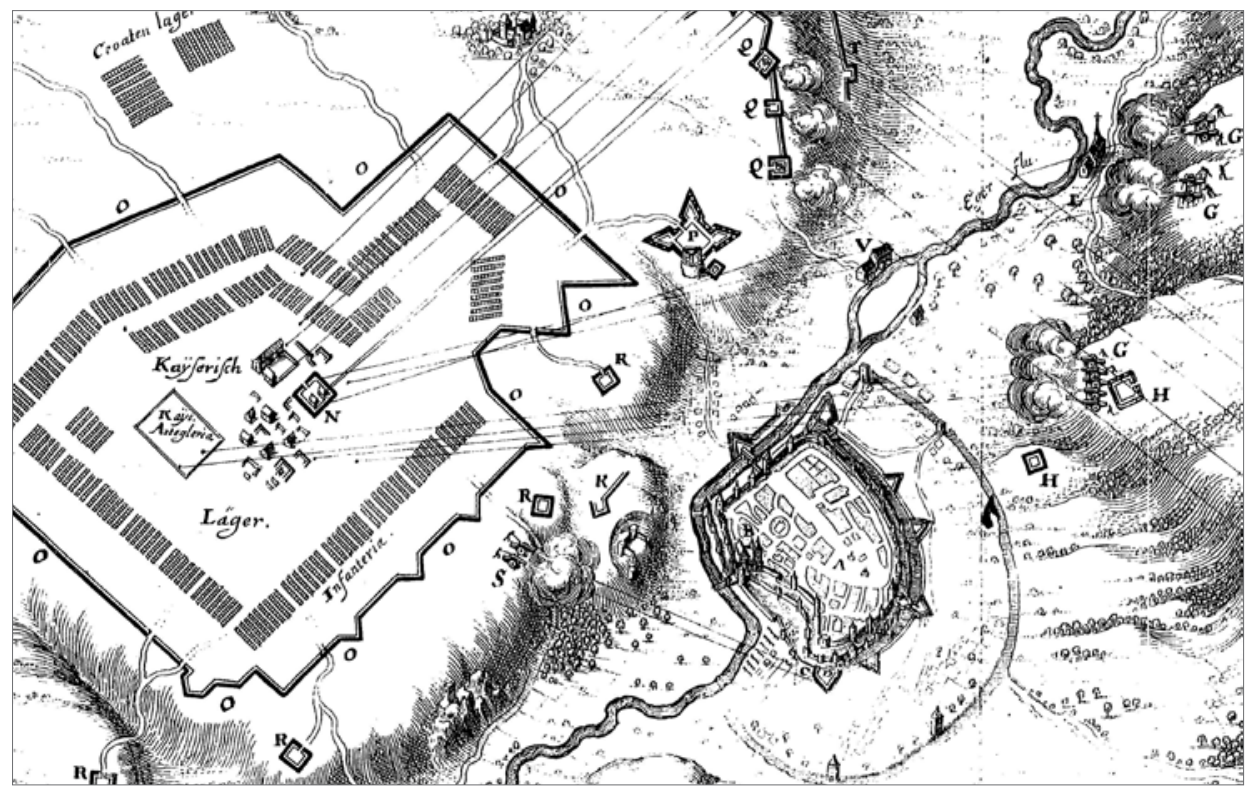

Obr. 8. Cheb, obléhání města v roce 1647. Zděná šibenice (uprostřed) byla díky své dominantní poloze nad městem začleněna do jedné z redut obléhatelů. Rytina Matthäuse Meriana, Theatrum Europaeum, 1663. Zdroj http://www.antiquariedel.com. Abb. 8. Cheb, Belagerung der Stadt im Jahr 1647. Der aufgemauerte Galgen (in der Mitte) wurde dank seiner dominanten Lage oberhalb der Stadt in eine der Reduten der Belagerer eingegliedert. Kupferstich von Matthäus Merian, Theatrum Europaeum, 1663. Quelle http://www.antiquariedel.com.

stínadel zobrazil Huss neobdělávanou plochu, ve svahu pod šibenicí vidíme naopak pole, sahající téměř až k vlastní šibenici.

Vzhled a využití krajiny v nejbližším okolí šibenice dobře přibližuje vyobrazení z pozdního středověku (obr. 12) zachycující na mírném návrší dvousloupovou dřevěnou šibenici, ohrazenou spolu s blízkým neudržovaným kolem jednoduchým vyplétaným plotem. V okolí se rozkládala obdělávaná pole, oddělená od popraviště pouze cestou a oplocením.

\section{Popraviště v kartografických pramenech}

Pro svou dominantní polohu se šibenice začaly objevovat v mapách již v době nastupující popularity mapových děl v 16. století (obr. 13). Nejspíše vzhledem k oblíbenosti map větších územních celků (zemí) a tomu odpovídající malé podrobnosti bylo však kartografické zobrazení šibenic spíše výjimečné. Četnost narůstala v průběhu 17. století v závislosti na tvorbě podrobnějších map a plánů zachycujících menší územní celky (obr. 14, 15, 21, 22). Pravidelnou součástí map se šibenice $\mathrm{v}$ našich zemích stávají až v rámci josefského mapování probíhajícího v letech 1764-1768 a rektifikovaného 1780-1783 (oldmaps.geolab.cz). Paradoxně šlo o dobu, kdy v důsledku reformy hrdelního soudnictví řada měst přicházela o hrdelní právo a šibenice začaly zanikat nebo byly záměrně odstraňovány. Takzvané I. vojenské mapování tedy zachycuje šibenice na samém sklonku jejich př́tomnosti v krajině (obr. 16-18).

Přibližně ve stejné době, tedy v 70.-80. letech 18. století, vznikaly tzv. raabizační mapy jednotlivých katastrů. Ačkoli to nebylo pravidlem, byla alespoň v některých případech v těchto mapách zachycena šibenice, zrrejmě jako jeden z orientačních bodů či důležitých objektů se vztahem k pozemkovým hranicím (obr. 20). 


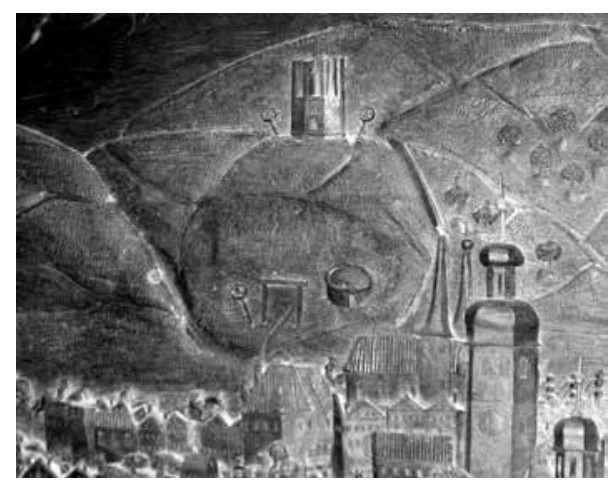

Obr. 9. Praha, útěk Fridricha Falckého z Prahy po bitvě na Bílé hoře, 1620. Dřevořez $K$. Bechtelera z roku 1623 v katedrále sv. Víta, Václava a Vojtěcha v Praze. Areál popraviště zřejmě v prostoru dnešního Žižkova se vstupní branou při úpatí, stínadly a zděnou šibenicí polygonálního půdorysu na temeni návrší. Archiv autora.

Abb. 9. Prag, Flucht von Friedrich von der Pfalz aus Prag nach der Schlacht am Weißen Berg, 1620. Holzschnitt von K. Bechteler aus dem Jahr 1623 in der Kathedrale der Heiligen Veit, Wenzel und Adalbert in Prag. Das Areal der Richtstätte wahrscheinlich im heutigen Prager Stadtviertel Žižkov mit Eingangstor am Bergfuß, Rabenstein und aufgemauertem Galgen mit polygonalem Grundriss auf dem Berggipfel. Archiv des Verfassers.

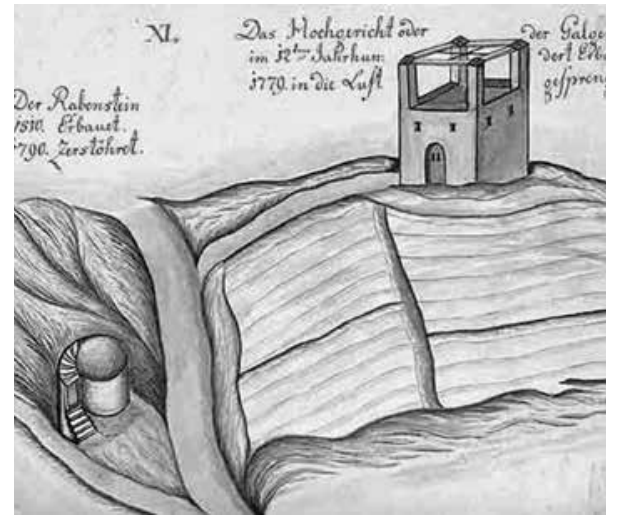

Obr. 11. Cheb, stínadla a šibenice na ilustraci z rukopisu posledního chebského kata Karla Hussa. Nad stínadly zobrazena neobdělávaná plocha prudšího svahu, pod šibenicí naopak pole. Zobrazení cest i terénu odpovídá skutečnosti. Muzeum Cheb, inv. č. N 2349.

Abb. 11. Eger, Rabenstein und Galgen auf einer Illustration aus der Handschrift des letzten Egerer Henkers Karl Huss. Oberhalb des Rabensteins wird die nicht bewirtschaftete Fläche eines Steilhanges dargestellt, unter dem Galgen umgekehrt ein Feld. Die Darstellung der Wege und des Geländes entspricht der Wirklichkeit. Museum Cheb, Inv.-Nr. N 2349.

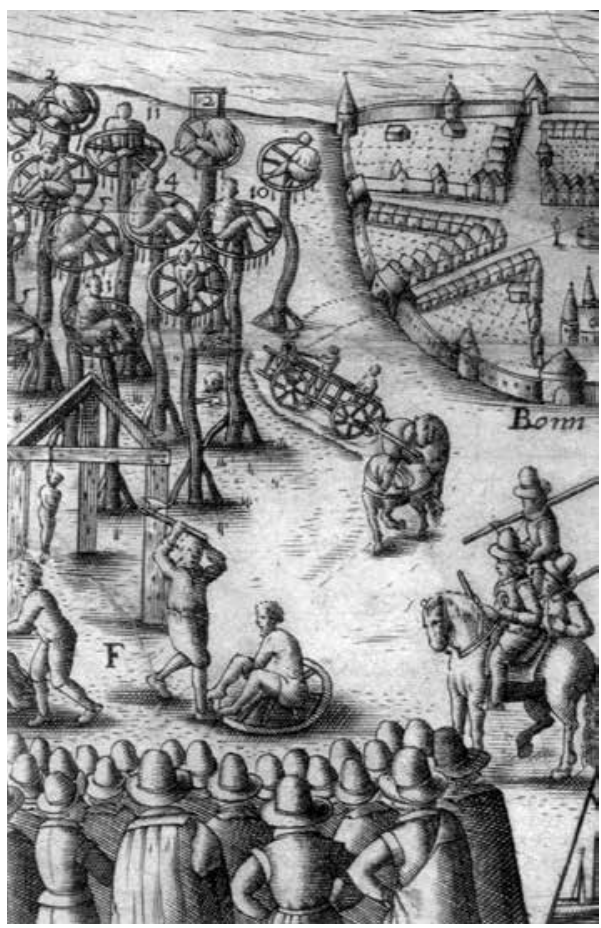

Obr. 10. Bonn, asi 1613. Vyobrazení areálu popraviště v blízkosti města. Podle Vogelfänger 2007.

Abb. 10. Bonn, ca. 1613. Darstellung des Areals der Richtstätte in Stadtnähe. Nach Vogelfänger 2007.

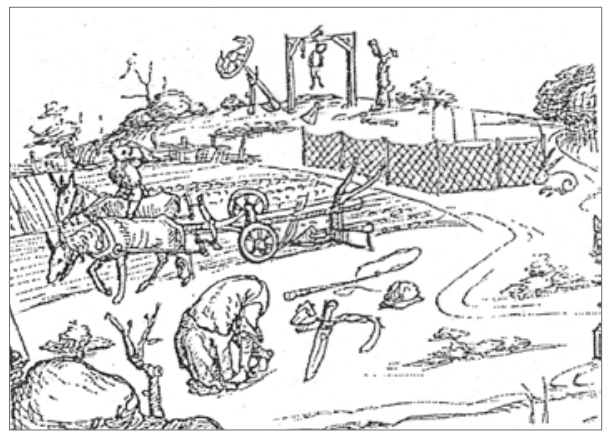

Obr. 12. Německo, konec 15. století. Vyobrazení zachycuje charakter krajiny v okolí šibenice: obdělávaná pole, oddělená od areálu popraviště jednoduchým plotem. Archiv autora.

Abb. 12. Deutschland, Ende 15. Jahrhundert. Die Darstellung erfasst den Charakter der Landschaft in der Umgebung des Galgens: bewirtschaftete Felder, die vom Areal der Richtstätte durch einen einfachen Zaun abgetrennt sind. Archiv des Verfassers. 


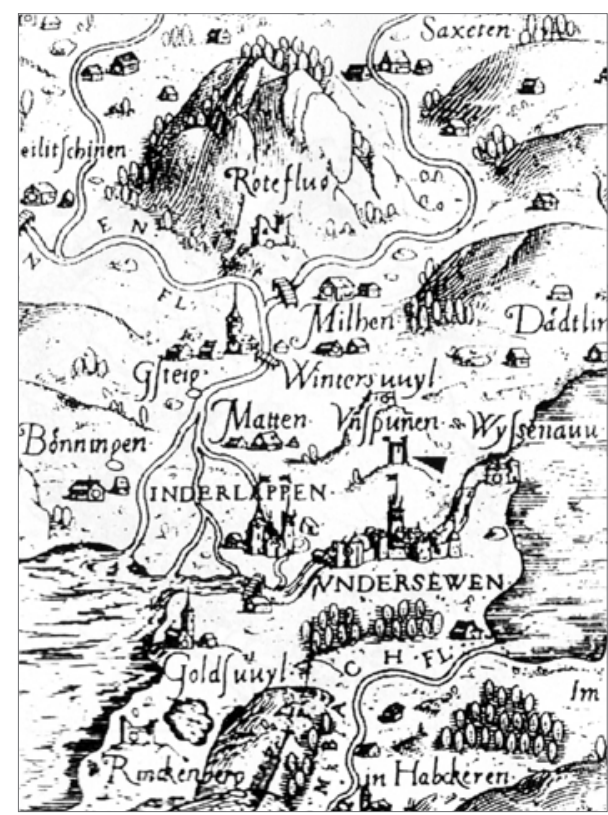

Obr. 13. Matten, Švýcarsko, mapa Thomase Schoepfla $z$ let 1577-1578. Zhruba uprostřed je zobrazena na jednom z návrší šibenice jako jedna $z$ dominant. Podle Ulrich-Bochsler-Gutcher 1993.

Abb. 13. Matten, Schweiz, Karte von Thomas Schoepfl aus den Jahren 1577-1578. Ungefähr in der Mitte wird auf einem der Hügel ein Galgen als eine der Dominanten dargestellt. Nach Ulrich-Bochsler-Gutcher 1993.

Chronologicky následovaly mapy stabilního katastru, vznikající pro Čechy v letech 1826-1843, pro Moravu a Slezsko 1824-1836 (oldmaps.geolab.cz). Ačkoli jsou tyto mapy, at' již jako tzv. indikační skici, nebo jako tzv. císařské otisky, často využívány pro studium krajiny a sídel, z hlediska studia popravišt' nepřináší podstatné informace. Vlastní výskyt objektů šibenic v krajině již nezaznamenávají, spolehlivé nejsou ani pro sledování pomístních jmen souvisejících s dřívější existencí popraviště.

Podobná je situace u tzv. II. vojenského mapování (Františkova) vznikajícího v letech 1836-1852 (oldmaps.geolab.cz). Kromě studia obecného vývoje krajiny a komunikací v okolí zaniklých popravišt' tyto mapy nic dalšího neumožňují. Lepší využití mají až mapy tzv. III. vojenského mapování (františko-josefského), probíhajícího na Moravě a ve Slezsku v letech 1876-1878, v Čechách 1877-1880 (oldmaps.geolab.cz). Tyto mapy zachycují již zpravidla pomístní názvy vztahující se k místům dřívější existence popravišt' (šibenic), a to v řadě českých i německých variant využívajících jak vlastní slovo šibenice (Galgen), tak i další pojmy vztahující se k výkonu hrdelního práva. Nejčastěji se objevují názvy jako: Šibeniční vrch, Šibenice,

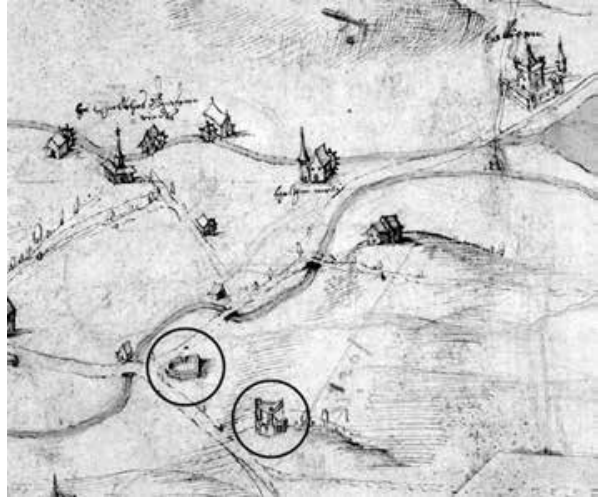

Obr. 14. Bern, mapa $z$ let 1620-1623 zachycuje kromě řady mlýnů a panského sídla zděnou šibenici se třemi pilíři na vyvýšenině při jedné z cest, nedaleko od ní na rozcestí pohřebiště popravenců v prostoru zrušené kaple. Podle Baeriswyl-Ulrich-Bochsler 2010.

Abb. 14. Bern, die Karte aus den Jahren 1620-1623 zeigt neben einer Reihe von Mühlen und einem Gutshof einen aufgemauerten Galgen mit drei Pfeilern auf einer Anhöhe an einem der Wege, in der Nähe davon befindet sich an einer Wegegabelung die Begräbnisstätte der Hingerichteten im Bereich einer aufgelösten Kapelle. Nach Baeriswyl-Ulrich-Bochsler 2010.

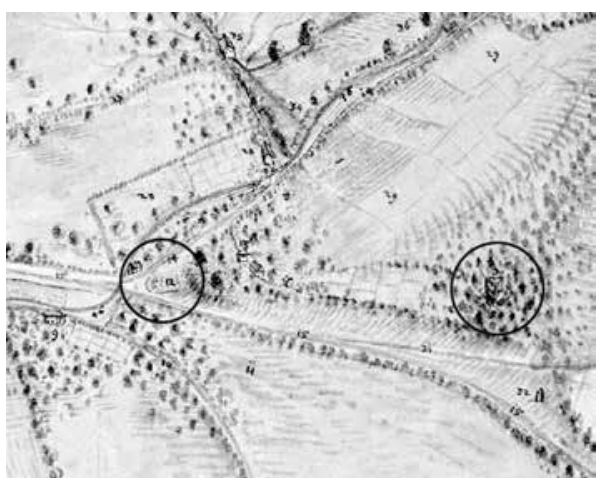

Obr. 15. Bern, mapa z roku 1663 zachycující stejný prostor jako na předchozím vyobrazení. Lépe je znázorněna struktura krajiny v okolí šibenice, tvořená polnostmi, sady a sítí cest se stromořadími. Podle Baeriswyl-Ulrich-Bochsler 2010.

Abb. 15. Bern, die Karte aus dem Jahr 1663 stellt den gleichen Raum wie auf der vorhergehenden Abbildung dar. Die Struktur der Landschaft in der Umgebung des Galgens wird besser veranschaulicht, sie besteht aus Feldern, Gärten und einem Wegenetz mit Baumreihen. Nach BaeriswylUlrich-Bochsler 2010. 


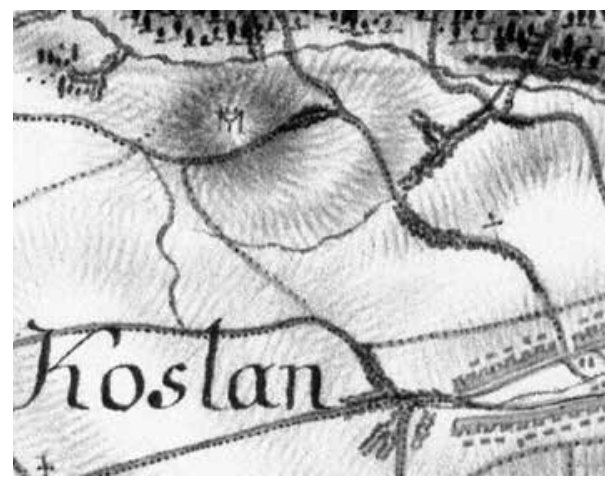

Obr. 16. Kožlany, okr. Plzeň-sever. Příklad vyobrazení šibenice na mapách I. vojenského mapování, v tomto př́ípadě situované na návrší v odlesněné krajině při jedné $z$ cest v blízkosti města. Zdroj http://oldmaps.geolab.cz.

Abb. 16. Kožlany, Bezirk Pilsen-Nord. Beispiel für die Darstellung eines Galgens auf den Karten der I. militärischen Kartierung, in vorliegendem Fall befindet sich der Galgen auf einer Anhöhe in einer entwaldeten Landschaft an einem in der Nähe der Stadt gelegenen Weg. Quelle http:// oldmaps.geolab.cz.

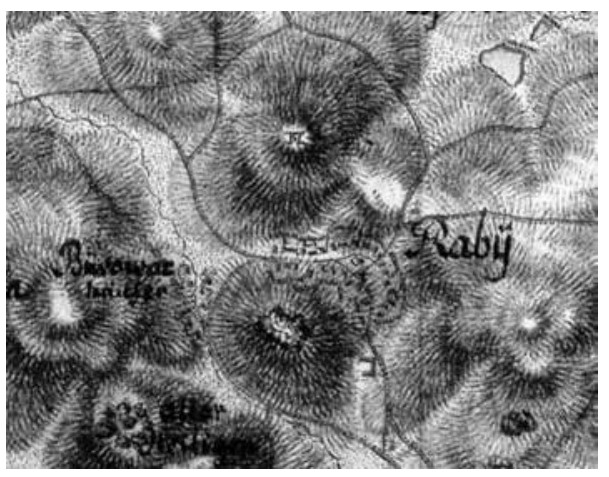

Obr. 18. Rabí, okr. Klatovy. I. vojenské mapování. Šibenice na výrazném kopci nad městečkem jako protipól návrší s hradem. Zdroj http://oldmaps.geolab.cz.

Abb. 18. Rabí, Bezirk Klatovy. I. militärische Kartierung. Galgen auf einem markanten Hügel oberhalb der Stadt als Gegenpol zur Burganhöhe. Quelle http://oldmaps. geolab cz.

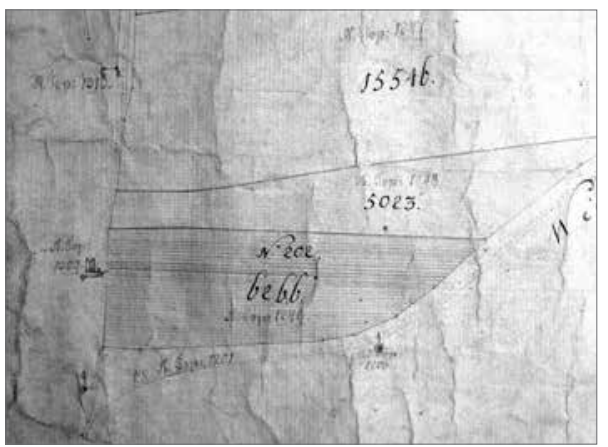

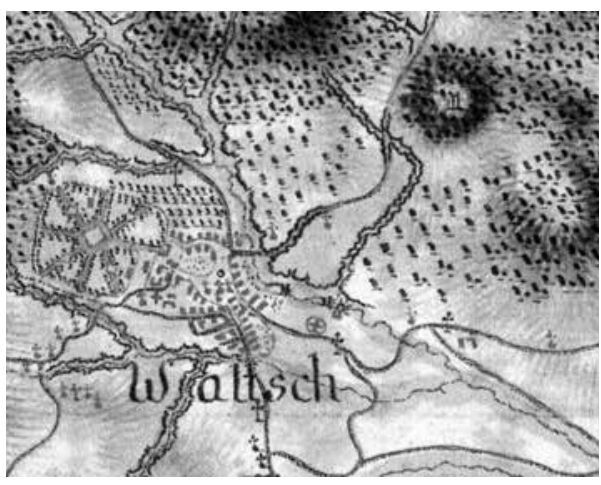

Obr. 17. Valeč, okr. Karlovy Vary. I. vojenské mapování. Šibenice umístěna na výrazný kopec na hranici intenzivně přetvářené barokní krajiny v okolí městečka a zámeckého areálu. Zdroj http://oldmaps.geolab.cz.

Abb. 17. Valeč, Bezirk Karlsbad. I. militärische Kartierung. Der Galgen befindet sich auf einem markanten Hügel an der Grenze zu einer intensiv umgestalteten Barocklandschaft in der Umgebung der Stadt und des Schlossareals. Quelle http://oldmaps.geolab.cz.

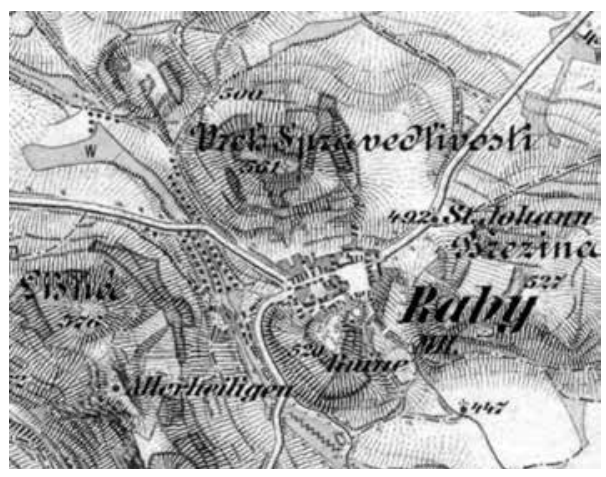

Obr. 19. Rabí, okr. Klatovy. III. vojenské mapování. Místo již zaniklé šibenice označeno pomístním názvem Vrch Spravedlivosti, uchovávajícím povědomí o původním využití lokality. Zdroj http://oldmaps.geolab.cz.

Abb. 19. Rabí, Bezirk Klatovy. III. militärische Kartierung. Der Ort des nicht mehr existierenden Galgens wurde mit dem Flurnamen Gerechtigkeitshügel bezeichnet, der das Bewusstsein über die ursprüngliche Nutzung des Ortes wachhält. Quelle http://oldmaps.geolab.cz.

Obr. 20. Plzeň, raabizační mapa z roku 1781 týkající se pozemků vsi Doubravka. V těsné blízkosti cesty a současně pozemkové hranice je na území města (při levém okraji) vyznačena šibenice s názvem „gericht“. Nedaleko jižním směrem rozcestí s božími muky. Archiv města Plzně, inv. č. M654. Podle Sokol-Hajšman 2010.

Abb. 20. Pilsen, die Raabisationskarte aus dem Jahr 1781 betrifft Ländereien des Dorfes Doubravka. In dichter Nähe eines die Grundstücksgrenze bildenden Weges ist auf dem Gebiet der Stadt (am linken Rand) ein Galgen mit dem Namen „Gericht“ eingezeichnet. In der Nähe in südlicher Richtung eine Wegegabelung mit Bildstöcken. Archiv der Stadt Pilsen, Inv.-Nr. M654. Nach Sokol-Hajšman 2010. 
Stará šibenice, Šibeník, Šiberná, Na spravedlnosti, Spravedlnost, Právo, Stínadla, Na stínadlech, v němčině pak Galgenberg, Hochgericht, Gericht, v latině Justitia. Obvykle, ve spojení se šibenicí, název odkazuje na charakter lokace zaniklého popraviště - na vyvýšeném místě (vrch, Berg). Existenci popraviště v takto označených místech lze potvrdit srovnáním s mapami I. vojenského mapování (obr. 18, 19), absence zobrazení šibenice na starší z nich však nemusí být spolehlivým důkazem o mylné lokaci pozdějšího pomístního názvu.

Kromě uvedených rozsáhlých mapových děl jsou převážně od 17. století pro řadu měst k dispozici jejich historické plány zachycující i okolí. I z nich lze vyčíst alespoň některé znaky umístění šibenic v krajině, nejčastěji jde o zdůraznění jejich vyvýšené polohy, vzdálenost od města a vztah k síti cest. Šibenice jsou na plánech zaznamenávány jako důležitý orientační bod v krajině (obr. 21, 22).

Vypovídací hodnota mapových děl je $\mathrm{z}$ hlediska studia vzhledu krajiny se zaměřením na lokaci popravišst' rozdílná. Liší se technika a způsoby zobrazení (schematické, realistické), míra přesnosti i podrobnosti. Kromě základních polohopisných informací se tak můžeme dozvědět i informace o charakteru reliéfu, způsobu využití a struktuře krajiny v okolí popravišt', zda šlo o plochy obdělávané, louky nebo plochy pokryté vzrostlou vegetací, jestli se vyskytovaly v okolí i další stavby a jakého typu, jak hustá byla sít' cest, zkrátka o celkovém prostorovém kontextu popravišt' (viz zejména obr. 14 a 15).

Zřejmě nejčastěji jsou za účelem studia historických šibenic využíány mapy josefského mapování. $\mathrm{Z}$ nich jsou obvykle $\mathrm{k}$ dispozici informace o existenci šibenice a o charakteru místa (reliéf, porost), situování vůči městu (vzdálenost) i cestám a průběh cest jsou však mnohdy

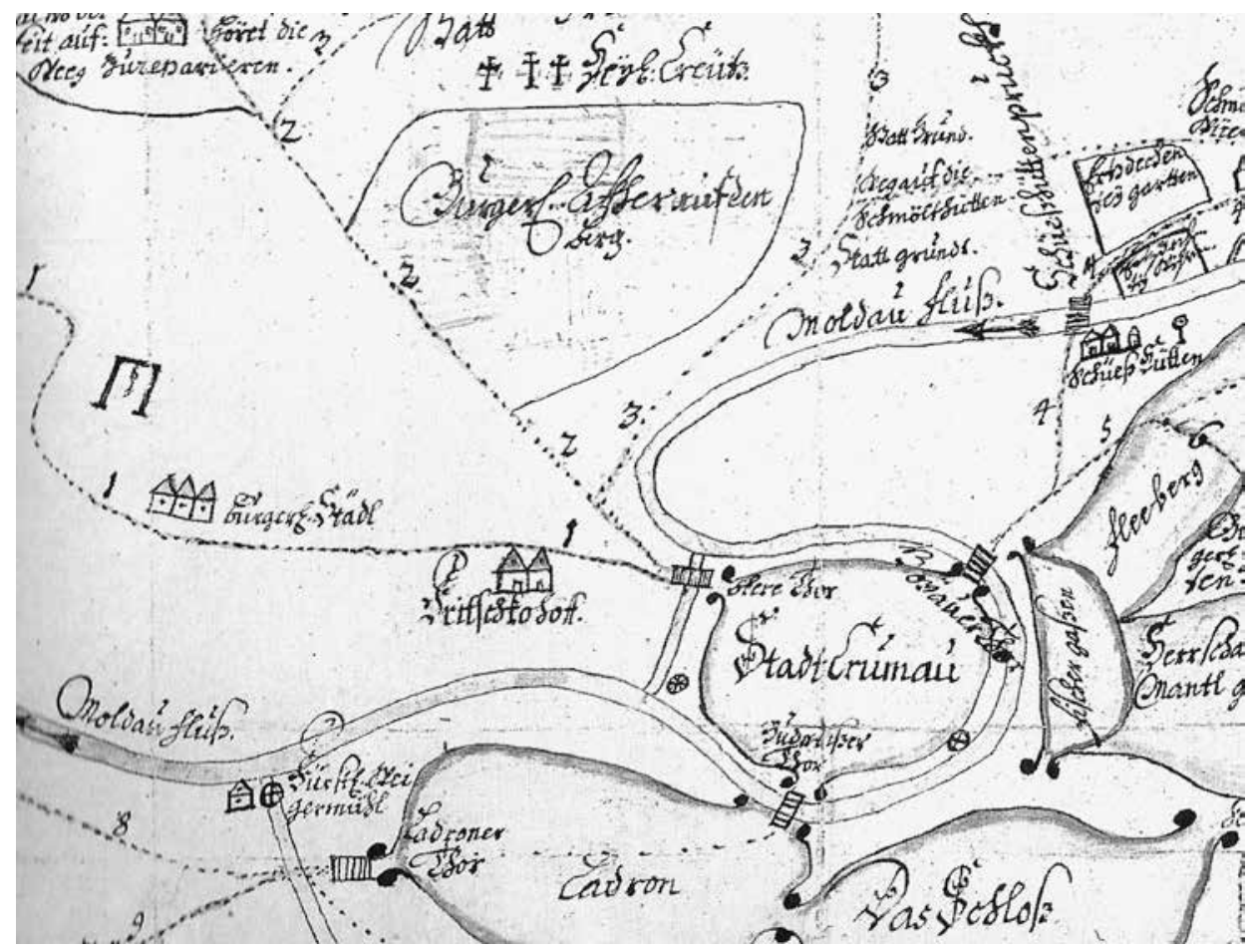

Obr. 21. Český Krumlov, plán města z konce 17. století. Kromě ploch městských částí, bran, předměstí a cest vyznačena jako důležitý orientační bod i šibenice (vlevo). Podle Kovář 2009.

Abb. 21. Český Krumlov, Stadtplan vom Ende des 17. Jahrhunderts. Außer den Flächen der Stadtteile, den Toren, der Vorstadt und Wege ist als wichtiger Orientierungspunkt auch ein Galgen (links) eingezeichnet. Nach Kovář 2009. 


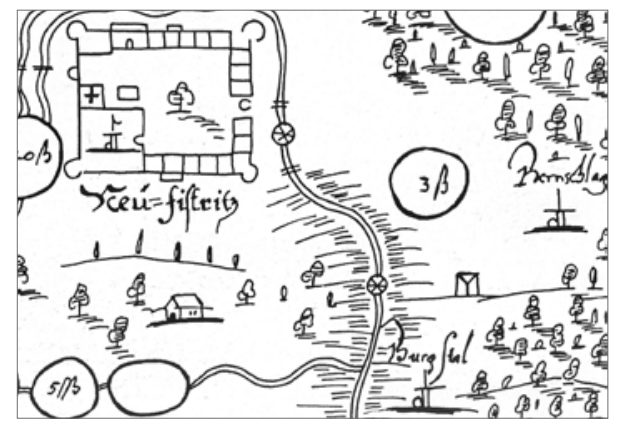

Obr. 22. Nová Bystřice, mapa bystřrického panství z roku 1654. Šibenice jako jeden $z$ důležitých orientačních bodů (vpravo). Podle Kovář 2009.

Abb. 22. Nová Bystřice, Karte der Grundherrschaft Bystřice aus dem Jahr 1654. Der Galgen als wichtiger Orientierungspunkt (rechts). Nach Kovář 2009. nepřesné (obr. 16-18). Problematičtější je i vlastní zobrazení šibenic ve vztahu k jejich stavebnímu typu a použitému stavebnímu materiálu (k tomu stručně také Kovář 2009, 184). Vzhledem ke způsobu vzniku josefských map je z hlediska prostorových vztahů potřebná komparace s mladšími mapami.

\section{Topografie popravišt’ na základě kartogra- fických a ikonografických pramenů}

Následující závěry nepředstavují detailní a úplné zpracování problematiky, jejich účelem je obecná charakteristika, kterou lze získat pouze pomocí vhodných ikonografických a kartografických pramenů, bez konkrétního vymezení geografické oblasti. ${ }^{3}$

Shrneme-li poznatky z ikonografických i kartografických pramenů vztahující se k vzhledu příměstské krajiny a umístění šibenic v ní, můžeme konstatovat následující. Potvrzuje se prostorová distribuce městských popravišt' v úzké souvislosti s typem popraviště a jeho př́íslušností ke konkrétní zóně městského nebo příměstského prostoru: 1) Uvnitř vlastního města, obvykle na náměstích, byla stavěna přechodná (jednorázová) či krátkodobá popravišš̌ (šibenice, stínadla), zejména s výstražným charakterem, v neklidné době nebo v důsledku nedostupnosti stabilního popraviště za městem. 2) V prostoru předměstí, tedy za pásem městských hradeb, stávala v některých městech stínadla. 3) Na okraji území města do zemědělsky využívaného městského zázemí nebo na jeho zadní hranici byly umístovány šibenice. Pro ně byly vybírány dominantní, nejčastěji vyvýšené (i když třeba nepatrně) polohy, dobře viditelné z širšího okolí. V př́stavních městech byly šibenice pojaty jako dominanty při vjezdu do př́stavu (k tomu též Evers 2008, 458), který nahrazoval podmínku blízkosti jedné z hlavních cest mezi městem a okolím (obr. 2325). Lokace šibenice vycházela přitom z požadavku jak na dostatečný odstup od města, aby její př́ítomností nedocházelo $\mathrm{k}$ znepř́íjemňování života ve městě, tak na nepř́iliš velkou vzdálenost z důvodů jejího využívání a symbolické role pro město spjaté, pokud to bylo možné, př́imým vizuálním kontaktem se šibenicí. Šibenice musela být i dopravně dostupná, což korespondovalo s podmínkou jejího umístění v blízkosti jedné z hlavních cest nebo poblíž rozcestí tak, aby její symbolika byla maximálně využita (obr. 26). Spolu s výše uvedenými požadavky na umístění šibenice měla být splněna i podmínka její stavby co nejblíže k hranicím pozemků města (například šibenice u Valče - obr. 17 - stávala na ostrohu, v jehož ose probíhala pozemková hranice, k tomu též obr. 20).

Prostor kolem šibenic byl volný, nezastavěný, jen občas se v okolí vyskytovaly vzrostlé stromy. Často do jejich blízkosti zasahovala pole nebo jinak využívané plochy. Při cestě k šibenici od města nebo již téměř u ní se obvykle nacházela boží muka. Vzhledem k charakteristice umístění představovaly šibenice při př́ijezdu k městu dominantu a často první objekt spojený $\mathrm{s}$ městem, kolem kterého př́ichozí k městu směřovali.

U stabilních, tedy nikoli př́íležitostných, stínadel byla situace vzhledem $\mathrm{k}$ jejich umístění i odlišnému vnímání poněkud jiná. Ačkoli šlo o stavby méně početné než šibenice, a proto je možné vycházet i z menšího počtu ikonografických pramenů, lze i tak s dostatečnou spolehlivostí

3 Konkrétní základní topografické údaje, jako je vzdálenost od města, převýšení, nadmořská výška a charakteristika umístění, jsou uváděny v pracích zabývajících se jednotlivými objekty (např. Kovář 2010; Sokol 2003a; 2011; 2016) nebo v pracích zabývajících se širším územím (např. Fröhlich 2006; Kováŕ 2009; Michálek 2006; Wojtucki 2009; naposledy Virdzeková 2016). Společně s vyhodnocením ikonografických a kartografických pramenů s důrazem na vývoj daného prostoru představují odlišnou úroveň zpracování cíleného na konkrétní území. Detailní zpracování vývoje a proměn místa se šibenicí s využitím kartografických a ikonografických pramenů představují např. studie k plzeňské šibenici a stínadlům SokolHajšman 2009; 2010; Sokol 2010; 2010a. Vzdálenost šibenic od města se pohybovala obvykle v těchto intervalech: 0,5-2,5km (Kováŕ 2009, 182-183), 0,5-2,1 km (Fröhlich 2006, 946), 0,5-3,5 km (Virdzeková 2016, 103), přičemž nejčastěji šlo o vzdálenost mezi $1 \mathrm{a} 1,5 \mathrm{~km}$. 


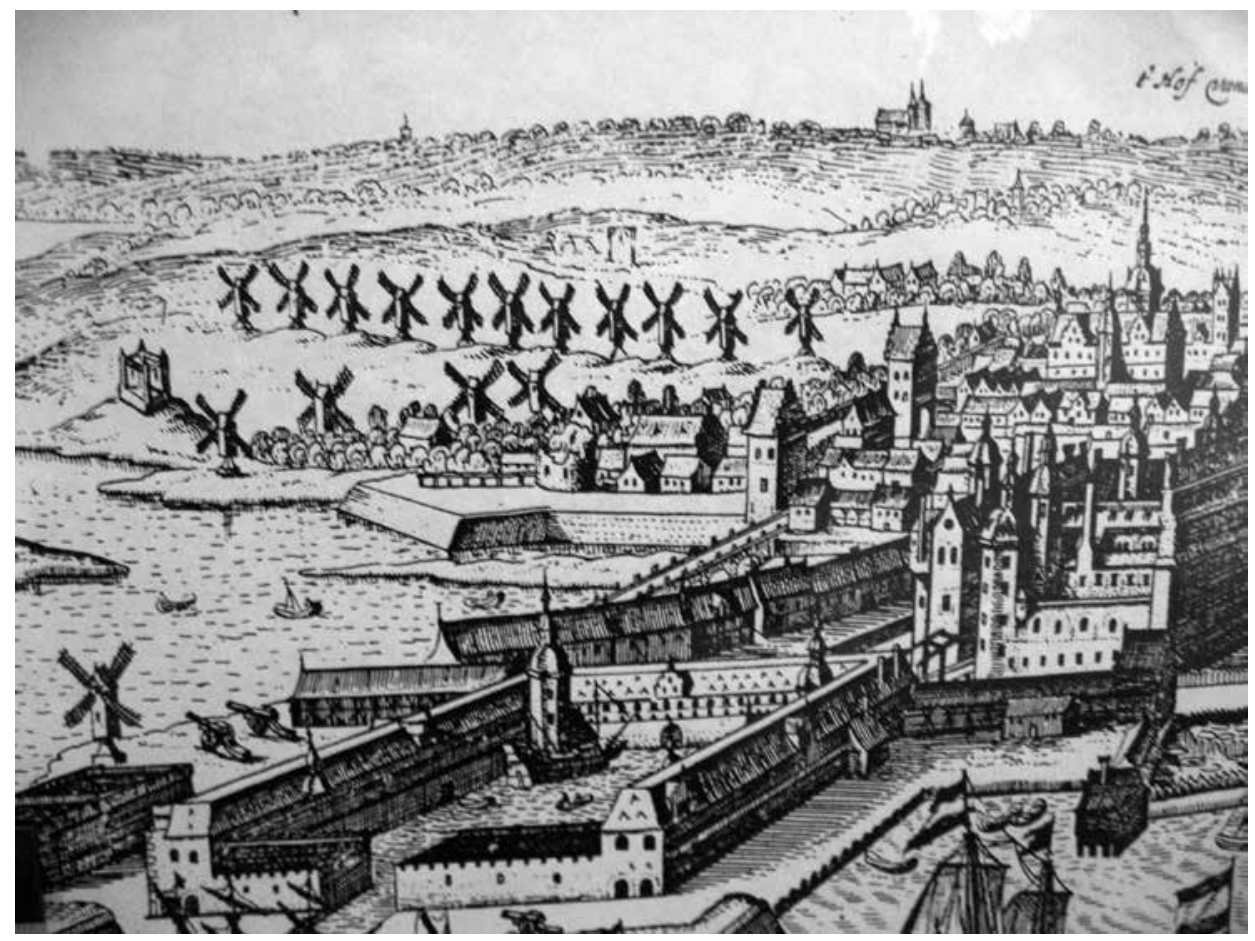

Obr. 23. Kodaň, veduta ze 17. století. Hlavní městská šibenice na vyvýšenině u př́stavu, druhá šibenice při cestě za městem. Archiv autora.

Abb. 23. Kopenhagen, Stadtansicht aus dem 17. Jahrhundert. Der städtische Hauptgalgen auf einer Anhöhe am Hafen, der zweite Galgen befindet sich an einem Weg hinter der Stadt. Archiv des Verfassers.

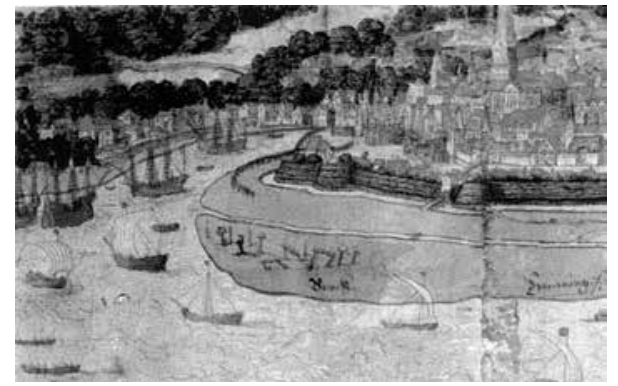

Obr. 24. Hamburk, 1568. Areál popraviště s dřevěnou šibenicí př̀i vjezdu do př́stavu. Podle Püschel 2007.

Abb. 24. Hamburg, 1568. Richtstättenareal mit Holzgalgen an der Hafeneinfahrt. Nach Püschel 2007. charakterizovat prostor, ve kterém se stínadla nacházela. Budována byla, jak už bylo řečeno, na předměstích, a v blízkosti některé $\mathrm{z}$ bran, $\mathrm{s}$ potřebným volným prostranstvím kolem. I u stínadel či přímo na nich se nacházela boží muka nebo drobná kaplička, př́ípadně pranýř. V okolí se vyskytovaly bud' hospodářské stavby, nebo byly sousední plochy využívány k pastvě (obr. 27-29). Obytné budovy se ke stínadlům dostávaly blíže než v př́ípadě šibenic.

Vzhled krajiny $\mathrm{v}$ okolí šibenic se po zániku jejich funkčnosti $\mathrm{v}$ mnoha prŕípadech změnil. U šibeničních vrchů došlo obvykle (ne vždy) k zalesnění vlastního vrcholku, tedy nejbližšího okolí šibenice. Důvodem byly majetkové vztahy (šibenice stála na obecním pozemku) a negativní vnímání místa. Zatímco polnosti nebo louky a pastviny pokrývaly svahy návrší a okrajové části vrcholku, ten často postupně zarostl malým lesem. Na mnoha šibeničních vrších došlo k změně reliéfu kupami kamene vysbíraného $\mathrm{z}$ okolních polí, $\mathrm{k}$ poničení místa šibenice těžbou kamene a zejména $\mathrm{v}$ průběhu 20. století stavbou specifických objektů (vodáren, vodojemů, triangulačních bodů, hvězdáren, meteorologických stanic, vysílačů, rozhleden; k tomu Kováŕ 2009, 183-186; Sokol-Hajšman 2010, 126-140). Př́istupové cesty od hlavní průběžné komunikace zpravidla zanikly. 


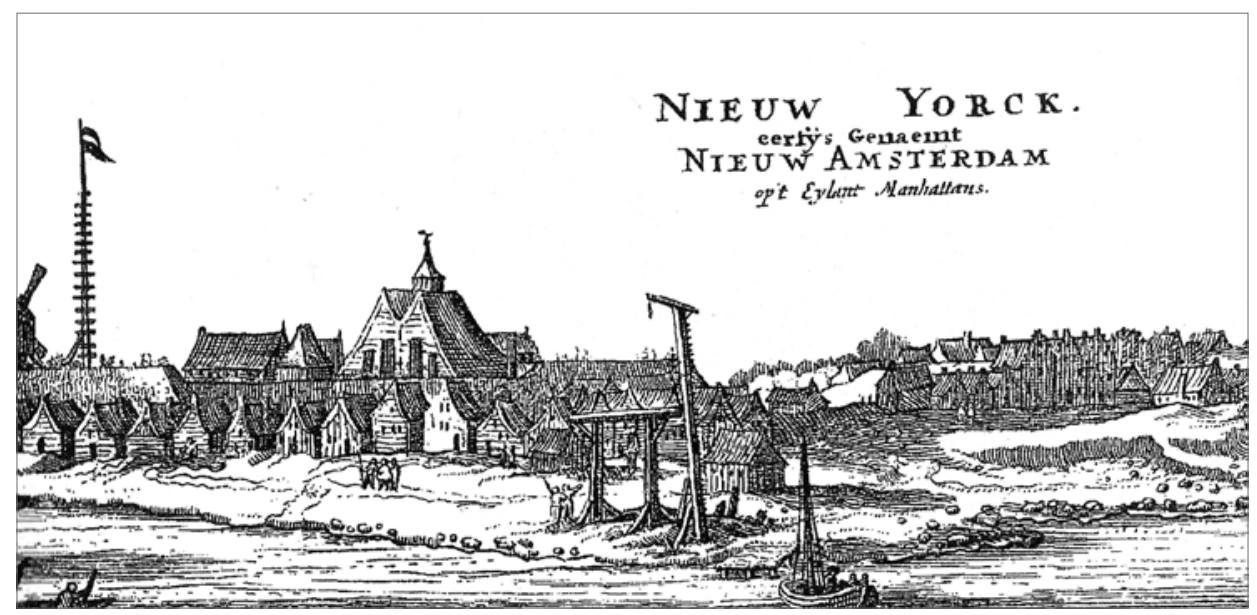

Obr. 25. New York, 2. polovina 17. století. Dřevěná šibenice v př́ístavu na ostrově Manhattan. Podle Klučina 2000. Abb. 25. New York, 2. Hälfte 17. Jahrhunderts. Holzgalgen am Hafen auf der Insel Manhattan. Nach Klučina 2000.

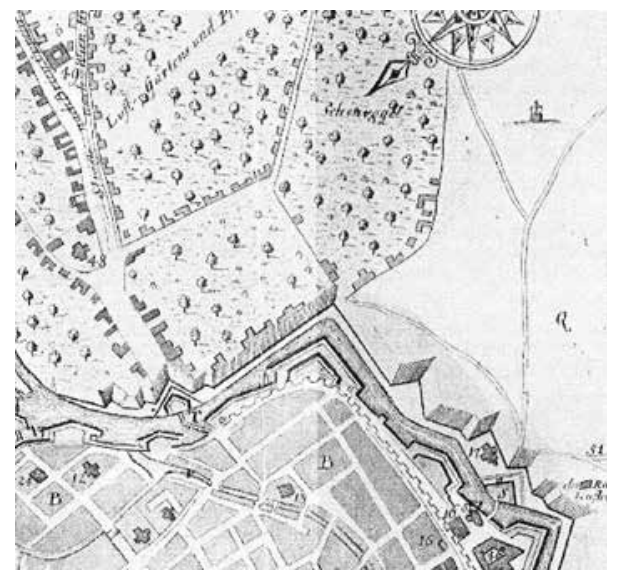

Obr. 26. Vratislav, mapa ze 17.-18. století. Šibenice u rozcestí jedné z hlavních cest (vpravo nahoře). Podle Wojtucki 2009.

Abb. 26. Breslau, Karte aus dem 17.-18. Jahrhundert. Galgen an der Gabelung einer der Hautwege (rechts oben). Nach Wojtucki 2009. dominant. Jako takové nacházely v časech válečných konfliktů i své vojenské využití. Šibenice se ve válečných časech mohla stát přirozeně předsunutým, i když špatně hájitelným opevněním města. Zdá se ovšem, že v př́ípadě obležení města sloužila častěji obléhatelům jako předsunutá pozice či týlová opora. Nelze vyloučit, že zobrazení poloh šibenic na válečných vedutách bylo schematické a neodpovídalo zcela reálným prostorovým vztahům. Přesto však četnost vyobrazení válečných akcí v blízkosti šibenice napovídá, že př̌i těchto př́ležitostech mohly být relativně dominantní polohy s těmito drobnými stavbami cíleně využívány.

Na vyobrazení bojů a válečných akcí bouřlivého 17. století se specializovala dílna Matthäuse Meriana staršího. Dílo Theatrum Europaeum obsahuje díky svému zaměření několik vedut 


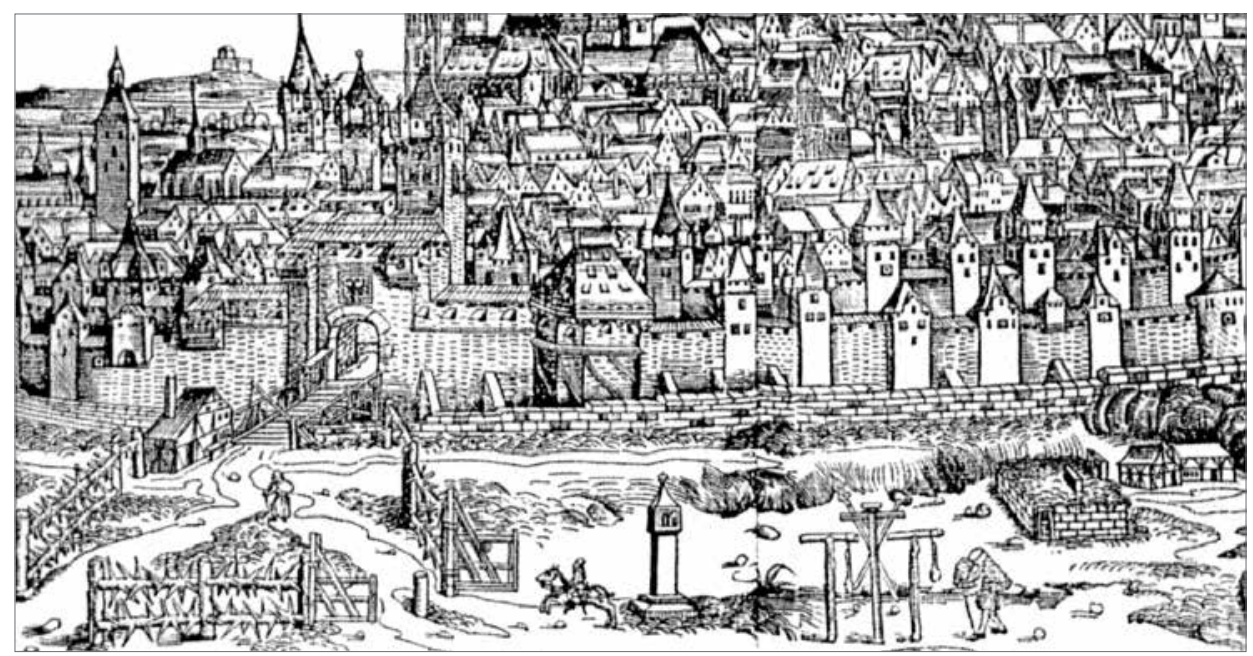

Obr. 27. Norimberk, H. Schedel, Liber chronicarum Norumberg, 1493-1496. Stínadla pravoúhlého půdorysu na předměstí (v pravém dolním rohu). Nezbytnou součást blízkého okolí představují boží muka. Podle Timmermann 2007.

Abb. 27. Nürnberg, H. Schedel, Liber chronicarum Norumberg, 1493-1496. Rabenstein mit rechteckigem Grundriss in der Vorstadt (in der rechten unteren Ecke). Einen untrennbaren Bestandteil der nahen Umgebung stellt der Bildstock dar. Nach Timmermann 2007.

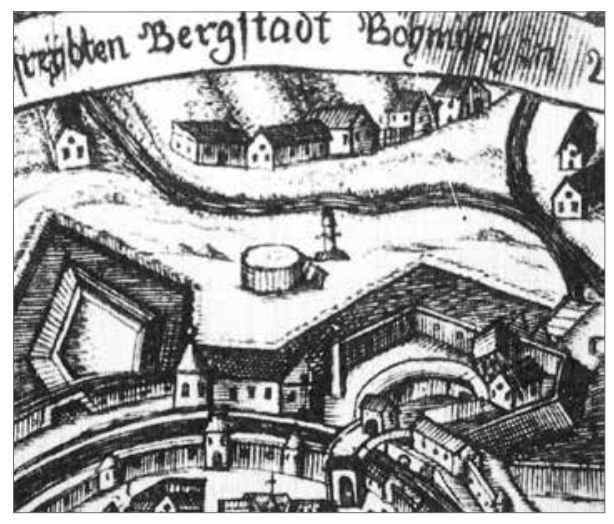

Obr. 28. České Budějovice, D. Wussin, 1665. Stínadla kruhového půdorysu před hradbami města. Zdroj http://encyklopedie.c-budejovice.cz.

Abb. 28. České Budějovice, D. Wussin, 1665. Rabenstein mit rundem Grundriss vor der Stadtmauer. Quelle http:// encyklopedie.c-budejovice.cz.

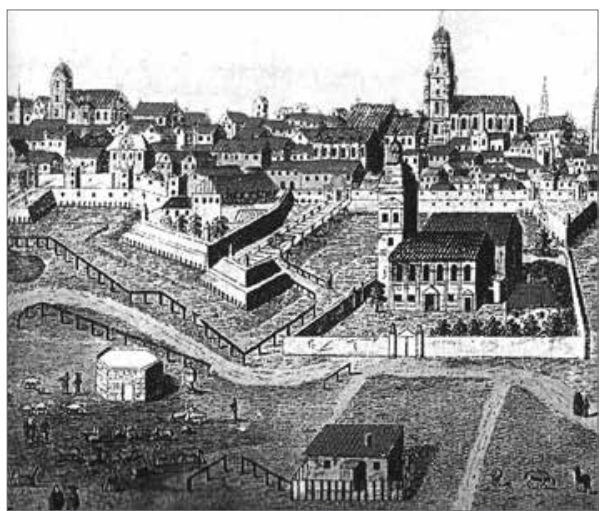

Obr. 29. Vratislav, polovina 18. století. Stínadla polygonálního půdorysu před hradbami města $v$ zatravněné ploše užívané k pastvě. Podle Wojtucki 2009.

Abb. 29. Breslau, Mitte 18. Jahrhundert. Rabenstein mit polygonalem Grundriss vor der Stadtmauer auf einer Weide. Nach Wojtucki 2009.

zachycujících využití šibenic při válečných akcích, čímž se liší od jiných větších souborů zobrazujících podobu raně novověkých šibenic.

Na vedutě z roku 1646 - pocházející z Merianovy dílny - zobrazující rozložení vojsk před bitvou u Lützenu 16. listopadu 1632 je týl císařské armády chráněn šibeničním vrchem s kruhovou, tř́ípilířovou šibenicí a vztyčenými koly pro vplétání těl odsouzencủ. Na shodně datovaném a méně schematickém vyobrazení již probíhající bitvy u Lützenu (obr. 7) vidíme v popředí tutéž šibenici, k níž se přiblížily hlavní boje a jejíž vyvýšená poloha se podle tohoto zobrazení stala oporou části císařského vojska. 
Čtyři jednoduché dřevěné dvoupilířové šibenice, jedna kolenová a čtyři vztyčená kola jsou zachyceny na vyobrazení města Wolffenbüttel v roce 1627 (Sokol 2008, 498). Popraviště je situováno na hranu říční terasy, již za linií obležení, jeho přímé zapojení do obléhacích akcí (snad vzhledem $\mathrm{k}$ absenci zděné stavby a $\mathrm{z}$ hlediska možností obléhatelů větší vzdálenosti od města) zde chybí. Nejde o jediný př́ípad, kdy šibenice, ač v dominantní poloze zůstala z nějakých důvodů obléhateli nevyužita. Naopak na vyobrazení z roku 1690 znázorňujícím obležení Memmingen $\mathrm{v}$ roce 1634 , na jeho spodním okraji, je šibenice, zřejmě tř́ípilířová, východně od města v úrovni linie obléhatelů a pod šibeniční vrch je umístěn vojenský oddíl, pravděpodobně dělostřelecký (Sokol 2008, 499). U Bernburgu je k roku 1644 zachyceno návrší s jednoduchou dřevěnou šibenicí ze tř́i sloupů zcela mimo vojenské tábory císařského i švédského vojska, vybudované na protějších březích řeky u města (Sokol 2008, 500). Šibeniční vrch se šibenicí nebyl využit pro opevnění švédského tábora (šibenice se nacházela na břehu pod jejich kontrolou) pravděpodobně pro nedostatečně velký prostor k zbudování rozlehlého tábora v její blízkosti - veduta zobrazuje v okolí šibenice vsi a vodní tok. Naproti tomu při obležení Schweinfurthu v roce 1647 byla zděná šibenice na výrazném vrchu využita v zadní linii obléhatelů jako jedno ze stanovišt' dělostřelby (Sokol 2008, 501). Na vyobrazení bojů o Prahu v roce 1648 je v detailu zachyceno rozmístění švédských baterií východně od městských hradeb, přičemž jedna z těchto dělostřeleckých baterií byla umístěna přímo na šibeničním vrchu u šibenice (Sokol 2008, 502).

Možné vojenské využití naznačuje i vyobrazení slezské Strzegomi z roku 1745, kde je na návrší sousedícím se šibenicí vyobrazeno dělostřelectvo, v prostoru za samotnou šibenicí pak jezdectvo (Sokol 2008, 503).

Nejjednoznačněji a vojensky nejaktivněji byla podle Merianem vydaných vyobrazení využita šibenice $\mathrm{v}$ Chebu v červenci 1647. Zděnou šibenici, která je zobrazena jako kruhová se třemi pilíri a umístěna od města přes řeku na blízkém vrchu (popis na vyobrazení přímo udává „Schantz auf dem galgenberg“), začlenili císařští do jedné z redut chránících jejich tábor na straně k městu a švédskému ležení. Šibenice nahradila jeden ze čtyř cípů reduty a na ni navazovalo drobné doplňující zemní opevnění (obr. 8). Šlo o důležité místo v obraně císařských, nebot' kolem šibenice a $\mathrm{k}$ ní připojeného opevnění stoupala cesta $\mathrm{z}$ města $\mathrm{k}$ vojenskému táboru. Existence šibenice tak zřejmě předurčila polohu opevnění a usnadnila vojákủm náročné zemní práce při jeho budování.

Zobrazená podoba chebské šibenice však přináší otázku věrohodnosti Merianových vedut ohledně stavebních detailů, nebot' zde vyobrazená kruhová šibenice je z doby o zhruba 150 let později známa jako stavba na čtvercovém půdorysu se čtyřmi zděnými pilíři. Vysvětlením může být př́ípadná pozdější přestavba šibenice v důsledku poničení staršího objektu nebo větší míra staršího typizovaného zobrazení bez nároků na dokumentační věrohodnost u některých prvků včetně šibenice. ${ }^{4}$ Její umístění i vedení blízké cesty na Merianově vedutě se však shodují s vyobrazením od posledního chebského kata Karla Hussa.

Uvedená zobrazení vojenských akcí s využitím šibenic či jejich poloh nejsou určitě zdaleka kompletní. Ovšem již v tomto množství ukazují, že využití dominantních poloh šibenic v blízkosti měst a někdy i př́ímo samotných zděných šibenic nacházelo v raně novověkém válečnictví uplatnění. V některých př́ípadech se o šibeniční vrch opíral týl vojska v bitvě, jindy byla šibenice využita jako součást linie opevnění obléhatelů měst. Městská stavba se tak stávala v dobách válečných konfliktů jako možný záchytný bod potenciálním nebezpečím pro město, podobně jako předměstí, která bývala někdy preventivně bourána, aby nemohla poskytnout oporu neprátelskému vojsku. O záměrném bourání šibenic před možným obležením však nejsou zprávy. Zřejmě i proto, že ve srovnání s předměstími šlo z hlediska možného rizika o mnohem méně podstatný prvek.

Vojenské využití šibenic s jejich výraznou polohou při bitvách či obležení měst však nemuselo být pravidlem. Základní podmínkou byl charakter reliéfu krajiny. Šibenice v extrémnější poloze, se stísněným okolím, členitým terénem a s horší dostupností (např. šibenice v Bečově

4 Obdobný, svou povahou však obecný problém (Evers 2008, 446) představují i vyobrazení plzeňské šibenice z roku 1601 a od roku 1619 do poloviny 17. století (Sokol-Hajšman 2010). 


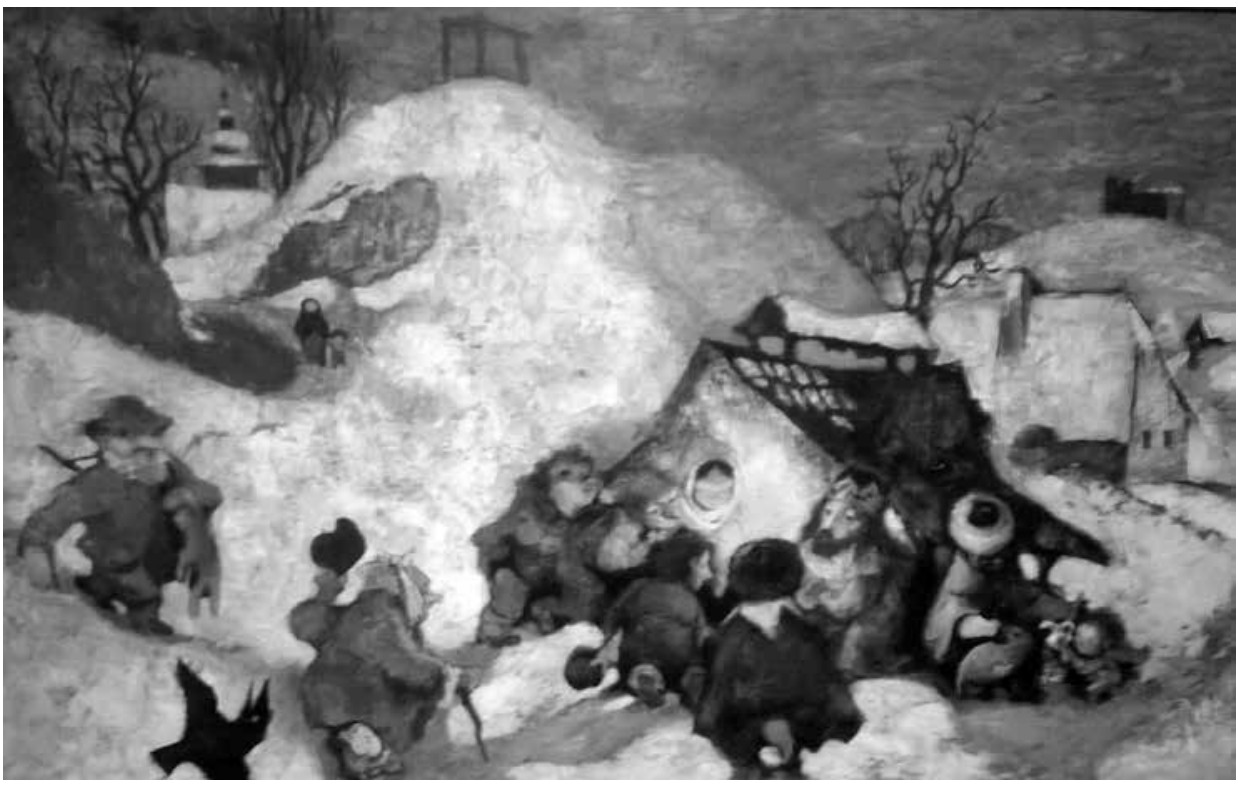

Obr. 30. J. Trnka: Betlém, olej 1942. Šibenice na kopci nad městem jako jeden ze symbolů tradiěního vnímání př́íměstské krajiny. Zdroj http://reprodukce.euweb.cz.

Abb. 30. J. Trnka: Krippe, ÖI 1942. Galgen auf einem Hügel oberhalb der Stadt als eines der Symbole, wie die Landschaft des Stadtumlandes traditionell wahrgenommen wurde. Quelle http://reprodukce.euweb.cz.

nad Teplou nebo u Přimdy - Sokol 2003; 2016) mohly být využity pro větší vojenské akce jen stěží a mohly plnit v lepším případě jen roli strážného místa (jako opora sloužily zřejmě takové šibenice i lapkům, kteří někdy v jejich blízkosti přepadávali - Sokol 2003, 47). Další komplikací byla nejspíš z hlediska vojenského využití vzdálenost větší, než jaká byla v daném případě optimální pro vybudování obléhací linie. Snad z takového důvodu se za linií ocitla šibenice u Wolffenbütelu. Podmínkou pro začlenění šibenice nebo šibeničního vrchu do linie obléhacího opevnění byla absence překážek mezi šibenicí a městem, pro využití šibenice jako opěrného bodu v bitvě či založení tábora byl potřebný dostatečný prostor v jejím okolí. Vliv mohla mít nakonec i skutečnost, zda šlo o šibenici zděnou, tedy pevnější, či jen dřevěnou.

\section{Shrnutí}

Popraviště, především pak šibenice, představovala dominantní prvek zázemí města. Jako jejich standardní součást se objevují na řadě vyobrazení měst i na mapách a plánech. Právě z ikonografických a kartografických pramenů lze studovat nejen vlastní typ popraviště a jeho topografickou charakteristiku (umístění popraviště vůči městu a cestám, morfologie místa s popravištěm, pomístní názvy), ale i vzhled okolní příměstské krajiny, jejíž součástí se popraviště stávala a již spoluvytvářela.

$\mathrm{Z}$ obou typů pramenů je zřejmé, že šibenice byly velmi nápadným prvkem v krajině. Bez ohledu na míru této nápadnosti sloužily jako důležitý orientační bod, představující podstatný prvek map a plánů, ke kterému bylo možno vztahovat prostorové vazby týkající se směrů, relativních vzdáleností, průběhu cest apod. Právě př́má vazba šibenice na jednu z hlavních cest (rozcestí) a snaha o výběr výraznější polohy jsou charakteristickými znaky lokace šibenic. Dalším kritériem pro výběr místa byla blízkost hranice extravilánu. V důsledku své relativně 
dominantní polohy vzhledem k okolí a blízkosti cest se šibenice stávaly potenciálními vojenskými opěrnými body a útočišti. Oproti tomu stínadla představovala často součást městské (předměstské) zástavby a v krajině na sebe nijak neupozorňovala.

Přítomnost šibenice indikovala určitý charakter příměstské kulturní krajiny. Okolí šibenice, pokud nešlo o šibenici dlouhodobě nevyužívanou, bylo nezalesněné a nezastavěné, do blízkosti šibenic zasahovaly hospodářsky využívané plochy (pole, louky, sady). Nedaleko se nacházela boží muka. Vzdáleností od cesty byla ovlivněna i míra provozu v nejbližším okolí popraviště. $V$ některých případech (zejména větší vrchy) byla šibenice vzhledem k poloze sice dobře viditelná, přesto však v odstupu od průběžné komunikace (např. Bečov nad Teplou, Přimda), $v$ jiných př́ípadech vedla tato komunikace $v$ těsné blízkosti popraviště a jeho prostor lze považovat za frekventovaný (např. Plzeň, Brno, Horní Slavkov).

Ačkoli šibenice byly součástí obhospodařované krajiny, svým účelem a tím, jak byly vnímány společností, se spolu se svým nejbližším okolím, využívaným k pohřbívání odsouzenců a sebevrahů, z tohoto území vydělovaly, což bylo často zhmotněno vymezením prostoru popraviště a jeho alespoň symbolickým oddělením od okolí.

Článek vznikl v rámci výzkumného cíle Archeologie (Průzkum archeologického potenciálu vybraných památkových území a objektů ČR) financovaného z institucionální podpory Ministerstva kultury na dlouhodobý koncepční rozvoj výzkumné organizace (DKRVO).

\section{Literatura}

BAERISWYL, A.-ULRICH-BOCHSLER, S., 2010: Bern, Brechbühlerstrasse 4-18, Schönberg Ost. Die bernische Richtstätte «untenaus», Archäologie Bern / Archéologie bernoise, 50-51.

EVERS, T., 2008: Richtstätten in zeitgenössischen Bildquellen. Typologie und Topographie. In: Richstättenarchäologie (Auler, J., ed.), 444-465. Dormagen.

FRANCEK, J., 1995: K vývoji hrdelního soudnictví v Čechách. In: Hrdelní soudnictví českých zemí. Soupis pramenů a literatury (Francek, J.-Štarha, I., edd.), 15-20. Praha.

FRÖHLICH, J., 2006: Poloha a podoba popravišt' Prácheňského kraje, ASČ 10, 945-957.

JEŽEK, M., 1996: Česká města na foliích würzburského alba (1. část), PRP 3, č. 2, 35-50.

KLUČINA, P., 2000: Třicetiletá válka. Obraz doby 1618-1648. Praha - Litomyšl.

KOVÁŘ, D., 2009: Historická popraviště Bechyňského kraje. Přehled a zhodnocení průzkumu z let 20062009, AVJČ 22, 177-258.

- 2010: Pozůstatky historických popravišt’ v jižních Čechách (Chvalšiny a Rožmberk nad Vltavou), Pomniki dawnego prawa 10, 38-45.

MARSCH, A.-BILLER, J. H.-JACOB, F.-D., edd., 2001: Die Reisebilder Pfalzgraf Ottheinrichs aus den Jahren 1536/1537 von seinem Ritt von Neuburg a.d. Donau über Prag nach Krakau und zurück über Breslau, Berlin, Wittenberg und Leipzig nach Neuburg. Weißenhorn.

MERGL, J., 1995: Plzeňské pohledy a veduty čtyř století 1500-1900. Plzeň.

MICHÁLEK, J., 2006: Topograficko-archeologický průzkum a výzkum šibenic v okrese Strakonice v letech 1995-2005, AVJČ 19, 303-323.

PÜSCHEL, K., 2007: Der Fall Störtebeker, Archäologie in Deutschland 2, 32-36.

ROUČKA, B., 1957: Poznámky k mapě hrdelních soudů v Čechách v první a ve druhé polovině 18. století, PHS 3, 115-133.

SOKOL, P., 2003: Hrdelní kriminalita v 16. a první polovině 17. století. Sonda do života a mentality obyvatel raně novověkého venkova, FHB 20 (2002), 7-106.

- 2003a: Šibenice v Bečově nad Teplou a archeologie popravišt' - The gallows at Bečov nad Teplou and the archaeology of places of execution, AR LV, 736-766.

- 2008: War, Town, Gallows. Some Aspects of Gallows on Historic Images. In: Richtsttätenarchäologie (Auler, J., ed.), 496-505. Dormagen.

- 2010: Gallows and Beheading Places in Pilsen. On Using of Pictorial, Cartographic, Written and Archaeological Sources. In: Richtstättenarchäologie 2 (Auler, J., ed.), 348-373. Dormagen.

- 2010a: Měla Plzeň stínadla? Interpretace dosud neznámé městské stavby. In: Dějiny staveb 2009. Sborník příspěvků z konference Dějiny staveb, 9-16. Plzeň. 
- 2011: Šibenice u Přimdy, okres Tachov. Z výsledků systematického povrchového průzkumu šibeničních vrchů západních Čech, AZČ 2, 182-188.

- 2016: Šibenice u Přimdy. Archeologický výzkum objektu se zvláštním symbolickým a sociálním významem - Ein Galgen bei Přimda. Archäologische Ausgrabung eines Objektes von besonderer symbolischer und sozialer Bedeutung, AH 41, 501-523.

SOKOL, P.-HAJŠMAN, J., 2009: Plzeňská „spravedlnost“. Lokalizace a proměny zaniklé městské stavby. In: Dějiny staveb 2008. Sborník příspěvků z konference Dějiny staveb, 155-170. Plzeň.

- 2010: Po stopách plzeňské spravedlnosti. Historie a topografie hrdelního soudnictví. Domažlice.

ŠTARHA, I., 1995: K vývoji hrdelního soudnictví na Moravě. In: Hrdelní soudnictví českých zemí. Soupis pramenů a literatury (Francek, J.-Štarha, I., edd.), 21-27. Praha.

TIMMERMANN, A., 2007: The Poor Sinners' Cross and the Pillory: Late Medieval Microarchitecture and Liturgies of Criminal Punishment, Umění LV, 362-373.

VOGELFÄNGER, T., 2007: Flurnahmendeutung - „Mord“ oder ,,am Ort“?, Archäologie in Deutschland 2 , 26-27.

VIRDZEKOVÁ, A., 2016: Stredoveké a rano-novoveké popraviská vo svetle archeologických prameňov. Magisterská diplomová práce, Ústav archeologie a muzeologie FF MU, Brno.

WOJTUCKI, D., 2009: Publiczne miejsca straceń na Dolnym Śląsku od XV do połowi XIX wieku. Katowice.

\section{Internetové zdroje}

http://encyklopedie.c-budejovice.cz/clanek/historiografie

http://oldmaps.geolab.cz

http://reprodukce.euweb.cz/pages/trnka_bet_kant.htm

ttp://www.antiquariedel.com/index.php?manufacturers_id=23\&filter_id=80\&language $=$ en $\&$ page $=1 \&-$ sort $=1 \mathrm{~d}$

https://cs.wikipedia.org/wiki/Soubor:Brno_Willenberg_1593.jpg

https://en.wikipedia.org/wiki/Battle_of_L\%C3\%BCtzen_(1632)

\section{Zusammenfassung}

\section{Der Galgen als Bestandteil der Kulturlandschaft der frühen Neuzeit}

Richtstätten, vor allem dann Galgen, stellten ein dominantes Element des Hinterlandes einer Stadt dar. Als ihr standardmäßiger Bestandteil tauchen sie auf einer Reihe von Abbildungen von Städten sowie auf Karten und Plänen auf. Gerade auf ikonographischen und kartographischen Quellen kann man nicht nur den Richtstättentyp selbst und dessen topographische Charakteristik (Lage der Richtstätte gegenüber der Stadt und Wegen, Morphologie des Richtstättenortes, Flurnamen), sondern auch das Aussehen der Vorstadtlandschaft studieren, zu deren Bestandteile Richtstätten wurden und diese bereits mitgestalteten.

An beiden Quellentypen wird deutlich, dass Galgen ein sehr auffälliges Element in der Landschaft waren. Ohne Rücksicht auf den Grad dieser Auffälligkeit dienten sie als wichtiger Orientierungspunkt, der ein wesentliches Element von Karten und Plänen darstellte, auf das man räumliche Bezüge hinsichtlich Richtung, relativer Entfernung, Wegeverläufe u.ä. beziehen konnte. Gerade der direkte Bezug eines Galgens zu einem Hauptweg (Wegegabelung) und das Bestreben, im Hinblick auf das Gelände eine markantere Lage auszuwählen, sind die charakteristischen Merkmale für die Ortswahl von Galgen. Ein weiteres Kriterium für die Wahl des Ortes war die Nähe zur Grenze des Außenbereichs einer Stadt. Infolge seiner relativ dominanten Lage im Hinblick auf die Umgebung und Nähe zu Wegen wurden Galgen zu potenziellen militärischen Stützpunkten und Zufluchtsorten. Rabensteine hingegen waren demgegenüber häufig Bestandteile der Bebauung einer Stadt (Vorstadt) und haben in der Landschaft keine Aufmerksamkeit auf sich gezogen.

Das Vorhandensein eines Galgens indizierte einen gewissen Charakter der Kulturlandschaft des städtischen Umlandes. Die Umgebung eines Galgens war, wenn es sich um keinen langfristig nicht genutzten Galgen handelte, nicht von einer Waldfläche bedeckt und unbebaut, 
wirtschaftliche Nutzflächen (Felder, Wiesen, Gärten) reichten bis in die Nähe von Galgen. In ihrer Nähe befanden sich Bildstöcke. Die Entfernung zu einem Weg hatte auch Einfluss auf das Verkehrsaufkommen in der Nähe des Raumes von Richtstätten. In einigen Fällen (besonders größere Hügel) war ein Galgen hinsichtlich seiner Lage zwar gut sichtbar, hatte trotzdem jedoch Abstand zu Durchgangsverkehrswegen (z.B. Bečov nad Teplou, Přimda), in anderen Fällen verlief dieser Verkehrsweg in dichter Nähe von der Richtstätte und ihr Raum kann als frequentiert angesehen werden (z.B. Pilsen, Brno, Horní Slavkov).

Obwohl Galgen Bestandteile einer bewirtschafteten Landschaft waren, haben sie sich durch ihren Zweck und dadurch, wie sie zusammen mit ihrer nächsten, zur Beisetzung von Verurteilten und Selbstmördern genutzten Umgebung von der Gesellschaft wahrgenommen wurden, von diesem Gebiet ausgenommen, was häufig dadurch Gestalt fand, dass der Raum einer Richtstätte abgegrenzt und er zumindest symbolisch von der Umgebung abgesondert wurde.

Der vorliegende Beitrag entstand im Rahmen des durch institutionelle Förderung einer langfristigen konzeptuellen Entwicklung der Forschungsorganisation (DKRVO) vom Ministerium für Kultur finanzierten Forschungsziels der Archäologie ((Untersuchung des archäologischen Potenzials ausgewählter Denkmalgebiete und -objekte Tschechiens).

Mgr. Petr Sokol, Národní památkový ústav, územní odborné pracoviště v Plzni, Prešovská 7, 30100 Plzeň, Česká republika, sokol.petr@npu.cz 
